\title{
Synthesis of 1,2,3-Triazole Benzophenone Derivatives and Evaluation of in vitro Sun Protection, Antioxidant Properties, and Antiproliferative Activity on HT-144 Melanoma Cells
}

\author{
Maria C. F. Dias, ${ }^{a}$ Bianca L. de Sousa, ${ }^{\circledR b}$ Marisa Ionta, ${ }^{c}$ Róbson R. Teixeira, ${ }^{\circledR *, b}$

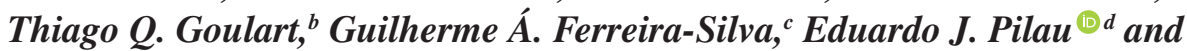 \\ Marcelo H. dos Santos ${ }^{\circledR b}$ \\ ${ }^{a}$ Instituto de Ciências Agrárias, Universidade Federal de Minas Gerais, \\ Avenida Universitária, 1000, Bairro Universitário, 39404-547 Montes Claros-MG, Brazil \\ ${ }^{b}$ Departamento de Química, Universidade Federal de Viçosa, \\ Avenida Peter Henry Rolfs, s/n, Campus Universitário, 36570-900 Viçosa-MG, Brazil \\ 'Instituto de Ciências Biomédicas, Universidade Federal de Alfenas, \\ Rua Gabriel Monteiro da Silva, 700, 37130-000 Alfenas-MG, Brazil \\ 'Departamento de Química, Universidade Estadual de Maringá, \\ Avenida Colombo, 5790, Campus Universitário, 87020-900 Maringá-PR, Brazil
}

\begin{abstract}
Benzophenones display several biological activities, including antioxidant, anticancer, and photoprotective. Furthermore, antioxidants can minimize both ultraviolet absorption and tumor development. In the present investigation, a series of twenty-six 1,2,3-triazole-benzophenone derivatives were synthesized and had their antioxidant, anticancer, and photoprotective effects evaluated. For the compounds synthesis, 4,4'-dihydroxybenzophenone (1a) and 2,4-dihydroxybenzophenone (1b) were propargylated, affording the alkynes bis(4-(prop-2-yn1-yloxy))benzophenone (2a) and (2-hydroxy-4-(prop-2-yn-1-yloxy))benzophenone (2b), respectively. The copper(I)-catalyzed azide-alkyne cycloaddition (CuAAC) reaction between the compounds $\mathbf{2} \mathbf{a} / \mathbf{2} \mathbf{b}$ and several benzyl azides gave the 1,2,3-triazole-benzophenone derivatives with yields ranging from 35 to $95 \%$. The 1,2,3-triazole-benzophenone derivatives at the concentration of $0.2 \mu \mathrm{g} \mathrm{mL}^{-1}$ (a no-cytotoxic concentration) exhibited a solar protection factor (SPF) comparable to positive control benzophonen-3 (BP-3). Concerning their antioxidant and cytotoxic effects, the derivatives from $\mathbf{1 b}$ showed high in vitro antioxidant effects as well as cytotoxicity against A549 (lung carcinoma), MCF-7 (breast carcinoma), and HT-144 (metastatic melanoma) cell lines, without significant cytotoxicity to a non-cancerous cell line. Derivatives 19, 20, and 24 induced cell death and cell cycle arrest at G1/S in HT-144 melanoma cells.
\end{abstract}

Keywords: benzophenone, 1,2,3-triazole, CuAAC reaction, antioxidant, photoprotective, cytotoxicity

\section{Introduction}

Benzophenones are a class of relevance to medicinal chemistry and industrial fields. ${ }^{1}$ These substances exhibit a wide spectrum of biological activities including antibacterial, ${ }^{2}$ anti-human immunodeficiency virus (HIV), ${ }^{3}$ antioxidant, ${ }^{4}$ and antitumor. ${ }^{5,6}$ Moreover, the role of the benzophenones and their derivatives as photoprotective agents has been well documented ${ }^{7-9}$ and some of them have been incorporated in sunscreen formulations. ${ }^{8,10}$

*e-mail: robsonr.teixeira@ufv.br
Hydroxybenzophenones, such as 2,4-dihydroxybenzophenone, 2,2',4,4'-tetrahydroxybenzophenone, and their derivatives, have a high ability to absorb and dissipate ultraviolet (UV) radiations, UVA and UVB. ${ }^{7}$ Excessive skin exposure to UVB radiation is related to photo-aging due to the degradation of important structures of the dermal extracellular matrix, such as elastin and collagen. ${ }^{11}$ These effects promoted by UVB exposure can be minimized by antioxidant agents, which include different types of substances. ${ }^{12,13}$

Phenolic compounds are an important class of antioxidants, particularly hydroxy benzophenones. ${ }^{14,15}$ 
For instance, it has been reported ${ }^{16}$ that garcinol, a natural polyisoprenylated and phenolic benzophenone extracted from the fruit peels of Garcinia indica, has high antioxidant activity being three times more potent towards 1,1-diphenyl2-picrylhydrazyl (DPPH) free radical than DL- $\alpha$-tocopherol. In another investigation, Doriguetto et al. ${ }^{17}$ evaluated the antioxidant activity of 2,2',4-trihydroxybenzophenone and compared its effect to the parent benzophenone. The 2,2',4-trihydroxybenzophenone was more active than benzophenone and this superior antioxidant activity was linked to the presence of the ortho-hydroxy groups. The authors ${ }^{17}$ also reported that these groups increase the hydrogen donation power due to the electronic delocalization of the unpaired electron of the generated phenoxy radicals.

Natural antioxidants protect the organism from cellular damage resulting from an excess of free radicals, which are responsible for inducing oxidative stress. Oxidative stress, in turn, is associated with many pathological conditions including cancer. ${ }^{18,19}$ Indeed, oxidative stress has an influence on tumor development and progression by modulating different biological processes including proliferation, survival, and invasion. ${ }^{20,21}$

Cancer is a leading cause of death worldwide. In 2018, there were 18 million new cancer cases and an increase of 21.6 million is estimated by $2030 .{ }^{22}$ Therefore, it is imperative to identify new substances that effectively could improve therapeutic propose for cancer. ${ }^{23}$ In the last years, extensive efforts have been made to find new, less toxic, and effective therapeutic drugs for cancer treatment.

Among the various strategies that have been used by the pharmaceutical industry to obtain new drugs, it stands out the use of click chemistry. Considering the products that can be obtained via the click chemistry approach, it should be mentioned substances bearing the 1,2,3-triazole ring, a well-recognized pharmacophoric group. ${ }^{24,25}$ The 1,2,3-triazole fragment is of great importance in medicinal chemistry and it has been involved in the synthesis of several heterocyclic compounds with important biological activities, including antibacterial, ${ }^{26}$ antifungal, ${ }^{26}$ for the treatment of Alzheimer's disease, ${ }^{27}$ anticancer, ${ }^{28,29}$ and antioxidant. ${ }^{30,31}$

The biological properties exhibited by both benzophenones and compounds containing the 1,2,3-triazole fragments, among them photoprotective, cytotoxic, and antioxidant, prompted us to design and synthesize new benzophenones bearing 1,2,3-triazole fragments aimed to find compounds with relevant biological effects. Herein, we describe the synthetic steps involved in the preparation of these new 1,2,3-triazolebenzophenone derivatives and the results related to the evaluation of their photoprotective, antioxidant, and cytotoxic activities.

\section{Results and Discussion}

The synthetic strategy used to prepare the 1,2,3-triazolebenzophenone derivatives is depicted in Figure 1. For their synthesis, it was required the preparation of several benzyl azides, which was carried out from the corresponding commercially available benzyl bromides and using procedures that have been described in the literature. ${ }^{32}$

The synthesis of the benzophenone derivatives containing 1,2,3-triazole fragments was performed in two steps. The first one corresponded to the propargylation reaction of 4,4'-dihydroxybenzophenone (1a) and 2,4-dihydroxybenzophenone (1b), producing the terminal alkynes bis(4-(prop-2-yn-1-yloxy))benzophenone (2a) and (2-hydroxy-4-(prop-2-yn-1-yloxy))benzophenone (2b) in 83 and $68 \%$ yields, respectively. Next, the copper(I)catalyzed azide-alkyne cycloaddition (CuAAC), also known as click reaction, between the alkynylated compounds $\mathbf{2 a / 2} \mathbf{b}$ and benzyl azides afforded the 1,2,3-triazole-benzophenone derivatives 4-29 (Figure 1) with yields in the range of 35 to $95 \%$. All the derivatives were characterized by infrared (IR) and ${ }^{1} \mathrm{H}$ and ${ }^{13} \mathrm{C}$ nuclear magnetic resonance (NMR) spectroscopies as well as high-resolution mass spectrometry (HRMS). In the ${ }^{1} \mathrm{H}$ NMR spectra, the hydrogen atoms of the methylene groups attached to nitrogen or oxygen were noticed as singlets within 5.42-5.61 and 5.20-5.25 ppm ranges. The signals for the hydrogens present in the triazolic rings were observed as singlets within 7.44-8.32 ppm range. The carbon chemical shifts are compatible with the structures of the compounds. Further, in the IR spectra, expected bands for functional groups were noticed. Finally, the molecular formulas of the triazolic derivatives were confirmed by HRMS analysis. The spectroscopic and spectrometric data of the 1,2,3-triazole-benzophenone derivatives are available in the Supplementary Information.

Once prepared, the compounds were submitted to biological assays to assess their photoprotective, antioxidant, and cytotoxic effects.

\section{In vitro sun protection factor (SPF) evaluation}

The 1,2,3-triazolic-benzophenone derivatives $\mathbf{2 a}, \mathbf{2 b}$, 4-7, 10, 11, 13, 15, 17-28 were evaluated regarding their in vitro $\mathrm{SPF}$ at $0.2 \mu \mathrm{g} \mathrm{mL}^{-1}$, a no-cytotoxic concentration. These compounds were selected since they were soluble in ethanol, the solvent used to conduct the assays. All compounds showed SPF approximately equal to 5.00 


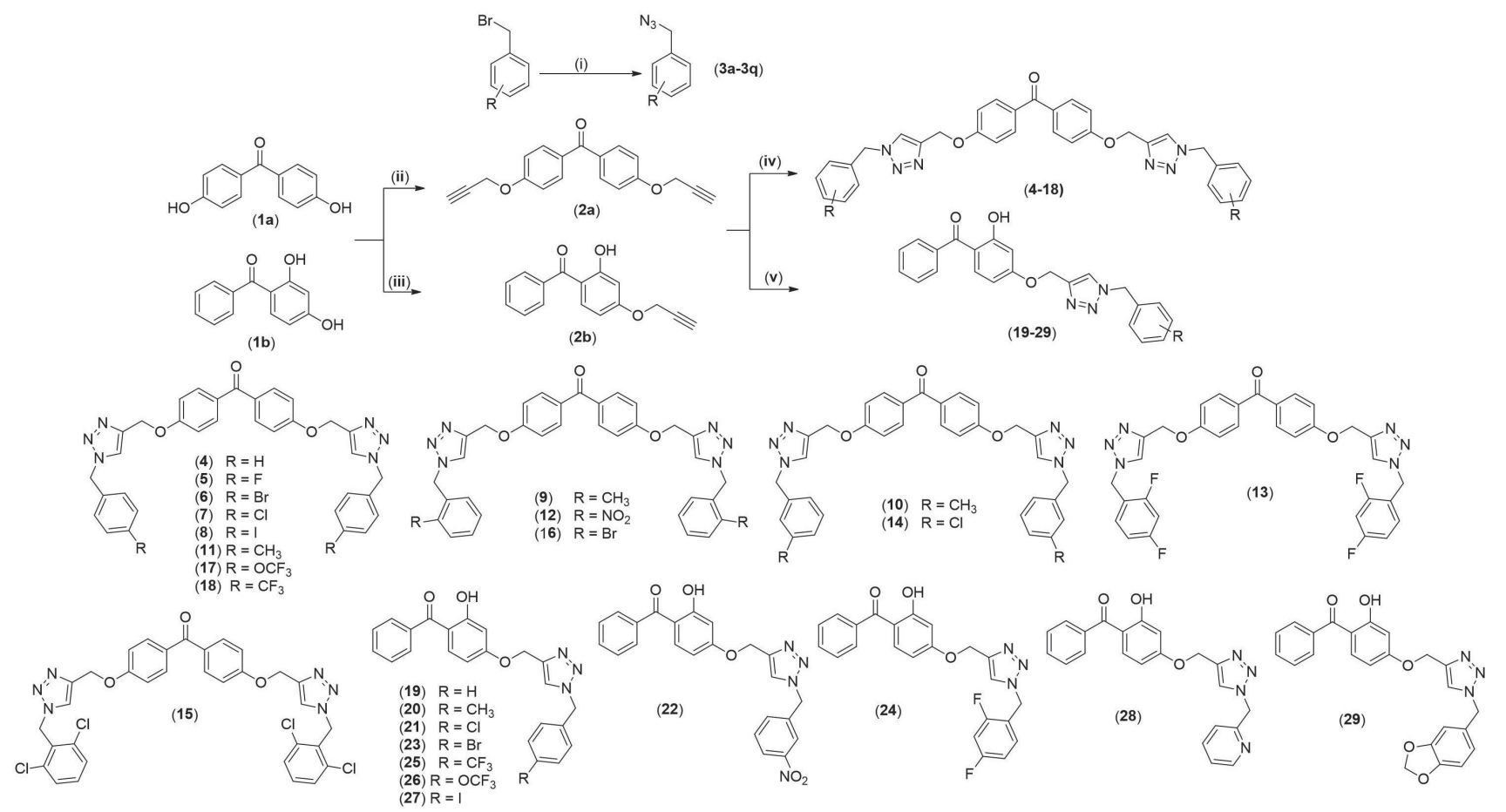

Figure 1. Reagents and conditions: (i) sodium azide (4.00 equiv.), DMSO, r.t., 2 h, $80-90 \%$ yield; (ii) propargyl bromide (2.40 equiv.), $\mathrm{K}_{2} \mathrm{CO}_{3}(4.00$ equiv.), acetone, reflux, $24 \mathrm{~h}, 83 \%$; (iii) propargyl bromide (1.20 equiv.), $\mathrm{K}_{2} \mathrm{CO}_{3}\left(2.00\right.$ equiv.), acetone, reflux, $24 \mathrm{~h}, 61 \%$; (iv) $\mathrm{CuSO}_{4} \cdot 5 \mathrm{H}_{2} \mathrm{O}(0.400$ equiv.), sodium ascorbate $\left(0.800\right.$ equiv.), $\mathrm{DCM} / \mathrm{H}_{2} \mathrm{O}(1: 1 \mathrm{v} / \mathrm{v})$, r.t., $6 \mathrm{~h}, 42-70 \%$; $(\mathrm{v}) \mathrm{CuSO}_{4} \cdot 5 \mathrm{H}_{2} \mathrm{O}(0.200$ equiv. $)$, sodium ascorbate $(0.400 \mathrm{equiv}),. \mathrm{DCM} / \mathrm{H}_{2} \mathrm{O}(1: 1 \mathrm{v} / \mathrm{v})$, r.t., 6 h, $35-95 \%$.

(Table 1). According to the Brazilian legislation (National Health Surveillance Agency (ANVISA) Resolution, ${ }^{34}$ RDC number 30, June 2012), the evaluated compounds have low photoprotective activity since the determined SPF values were smaller than or equal to 6.0. Statistical analyses were performed for comparison between the SPF values of triazolic derivatives and benzophenone-3 (BP-3). Only compound 18 presented statistical difference as compared to the positive control BP-3 $(p<0.05)$.

Brazilian legislation (ANVISA Resolution, ${ }^{35}$ RDC number 48, 2006) also requires, for sunscreen efficacy and safety, the following attributes for compounds to be used in sun protection products: $(i)$ UV light absorption in the range $280-400 \mathrm{~nm}$; (ii) molar absorptivity $(\varepsilon)$ above $10^{4} \mathrm{M}^{-1} \mathrm{~cm}^{-1}$; (iii) low water solubility. The compounds 2a, 2b, 4-7, 10, 11, 13, 15, 17-28 presented UV absorption near to $290 \mathrm{~nm}$ (see Supplementary Information, Figure S113). As can be noticed in Table 1 , the molar absorptivities of triazolic derivatives are in agreement with the legislation. Water solubility can be associated with MlogP $(\log \mathrm{P}$ calculated by the Moriguchi method using MedChem Designer ${ }^{\odot}$ 3.1.0.30 software). ${ }^{33}$ We found MlogP values between 3.54 and 5.28 to triazolic derivatives and 4.20 to BP-3. These values indicated that compounds present water solubility comparable to BP-3. Taking together, the data show that the properties of all benzophenone derivatives synthesized in this work are in consonance with Brazilian legislation ${ }^{34,35}$ concerning photoprotective substances.

The penetrability of compounds used in sunscreen formulations into the skin is affected by their molecular weights. Compounds presenting molecular weights below 500 Daltons can easily penetrate the skin's barrier and be absorbed..$^{36}$

Benzophenones typically used as UV filters and absorbers, such as BP, BP-1, and BP-3, have low molecular weight (below 500 Daltons) and, as a result, can diffuse through the skin and accumulate in the body. The diffusion of benzophenone can make the skin more susceptible to exposure to UV radiation. Besides, the aforementioned benzophenones are endocrine disruptors and their presence inside the body can interfere with several biological processes. ${ }^{37}$ Thus, the increase in the molecular weight of benzophenone derivatives prevents their penetration through the skin. The triazole derivatives 5-7, 10, and 11 showed molecular weight values greater than 500 Daltons (Table 1). In addition, the derivatives of hydroxylated benzophenones showed molecular weight values similar to compounds patented and currently used in the market in the composition of cosmetic products intended to protect the skin against the deleterious effects of UV light radiation. ${ }^{38}$ 
Table 1. Solar protection factor (SPF) values (at the concentration of $0.2 \mu \mathrm{g} \mathrm{mL}^{-1}$ ), molar absorptivity ( $(\varepsilon)$, molecular weight (MW) and MlogP for the benzophenone derivatives. Benzophenone-3 (BP-3) was used as positive control

\begin{tabular}{|c|c|c|c|c|}
\hline Compound & SPF & $\varepsilon /\left(\times 10^{5} \mathrm{M}^{-1} \mathrm{~cm}^{-1}\right)$ & $\mathrm{MW} / \mathrm{Da}$ & $\mathrm{M} \log \mathrm{P}$ \\
\hline $2 a$ & $5.20 \pm 0.014$ & 8.62 & 214.22 & 2.92 \\
\hline $2 \mathbf{b}$ & $5.20 \pm 0.036$ & 7.49 & 290.32 & 3.74 \\
\hline 4 & $5.21 \pm 0.079$ & 16.29 & 252.27 & 3.61 \\
\hline 5 & $5.12 \pm 0.070$ & 16.51 & 592.61 & 4.21 \\
\hline 6 & $5.16 \pm 0.077$ & 18.09 & 831.96 & 4.40 \\
\hline 7 & $5.14 \pm 0.027$ & 20.58 & 628.59 & 4.58 \\
\hline 10 & $5.20 \pm 0.024$ & 17.10 & 724.62 & 4.58 \\
\hline 11 & $5.06 \pm 0.056$ & 16.68 & 692.62 & 4.93 \\
\hline 13 & $5.07 \pm 0.032$ & 19.64 & 385.42 & 4.58 \\
\hline 15 & $5.16 \pm 0.051$ & 20.08 & 399.45 & 4.58 \\
\hline 17 & $5.11 \pm 0.038$ & 19.89 & 419.87 & 4.58 \\
\hline 18 & $4.94 \pm 0.023^{\mathrm{a}}$ & 19.71 & 430.42 & 4.93 \\
\hline 19 & $5.27 \pm 0.057$ & 12.48 & 464.32 & 3.83 \\
\hline 20 & $5.27 \pm 0.077$ & 11.39 & 421.4 & 5.28 \\
\hline 21 & $5.19 \pm 0.007$ & 11.94 & 469.42 & 3.78 \\
\hline 22 & $5.14 \pm 0.033$ & 12.14 & 511.32 & 3.99 \\
\hline 23 & $5.32 \pm 0.157$ & 13.44 & 386.41 & 3.99 \\
\hline 24 & $5.21 \pm 0.063$ & 12.36 & 214.22 & 3.63 \\
\hline 25 & $5.23 \pm 0.061$ & 13.29 & 290.32 & 4.09 \\
\hline 26 & $5.11 \pm 0.046$ & 13.08 & 252.27 & 3.99 \\
\hline 27 & $5.20 \pm 0.027$ & 14.91 & 592.61 & 4.30 \\
\hline 28 & $5.21 \pm 0.044$ & 11.26 & 831.96 & 3.54 \\
\hline BP-3 & $5.22 \pm 0.128$ & 6.00 & 628.59 & 4.20 \\
\hline
\end{tabular}

${ }^{\mathrm{a}} p<0.05$ according to ANOVA followed by Tukey's post-test. MlogP values ( $\log \mathrm{P}$ calculated by the Moriguchi method) were obtained from MedChem Designer ${ }^{\odot}$ 3.1.0.30 software. ${ }^{33}$

\section{Antioxidant activity}

Antioxidant activity of the 1,2,3-triazole-benzophenone derivatives was determined considering their ability to react with the stable radical DPPH. Just compounds soluble in ethanol, the solvent used to conduct the assays, were tested. This spectrophotometric method is based on the reduction of DPPH by an antioxidant compound, resulting in a colorless solution. As a consequence, the absorbance decreases. ${ }^{39}$ The antioxidant effect was expressed as the Trolox equivalent antioxidant capacity (TEAC) and the values are shown in Table 2.

The 4,4'-dihydroxybenzophenone derivatives $\mathbf{2 a}$, $\mathbf{5}, \mathbf{8}, \mathbf{1 3}, \mathbf{1 7}, \mathbf{1 8}$ showed low TEAC, being $\mathbf{5}$ and $\mathbf{1 7}$ the compounds that displayed lower values, compared to $\mathbf{2 a}$, for both experimental times. The derivatives $\mathbf{8}, \mathbf{1 3}$, and $\mathbf{1 8}$ presented greater antioxidant activity than $\mathbf{2} \mathbf{a}$, with no statistical difference among the 1,2,3-triazoles.
Table 2. Trolox equivalent antioxidant capacity (TEAC) for 1,2,3-triazolebenzophenone derivatives. The TEAC is related to the antioxidant capacity of a given substance, as compared to the standard Trolox

\begin{tabular}{|c|c|c|}
\hline \multirow{2}{*}{ Compound } & \multicolumn{2}{|c|}{ TEAC / $\left(\mathrm{mmol} \mathrm{L}^{-1} \mathrm{~g}^{-1}\right)$} \\
\hline & After $2 \mathrm{~h}$ & After $4 \mathrm{~h}$ \\
\hline $1 b$ & $5.96 \pm 0.769^{a}$ & $7.57 \pm 1.635^{\mathrm{a}}$ \\
\hline $2 a$ & $4.77 \pm 0.092^{\mathrm{b}}$ & $4.39 \pm 0.404^{\mathrm{a}, \mathrm{b}}$ \\
\hline $2 b$ & $22.61 \pm 0.743^{\mathrm{c}}$ & $22.91 \pm 0.267^{\mathrm{c}}$ \\
\hline 5 & $2.16 \pm 0.462^{\mathrm{d}}$ & $2.24 \pm 0.195^{\mathrm{b}, \mathrm{d}}$ \\
\hline 8 & $7.12 \pm 0.109^{\mathrm{a}, \mathrm{b}, \mathrm{e}}$ & $8.16 \pm 0.528^{\mathrm{a}, \mathrm{e}}$ \\
\hline 13 & $7.64 \pm 0.350^{\mathrm{a}, \mathrm{e}, \mathrm{f}}$ & $9.51 \pm 0.460^{\mathrm{a}, \mathrm{e}, \mathrm{f}}$ \\
\hline 17 & $2.09 \pm 0.063^{\mathrm{d}, \mathrm{g}}$ & $2.42 \pm 0.705^{\mathrm{b}, \mathrm{d}, \mathrm{g}}$ \\
\hline 18 & $7.68 \pm 0.816^{\mathrm{a}, \mathrm{e}, \mathrm{f,h}}$ & $9.44 \pm 0.081^{\mathrm{a}, \mathrm{e}, \mathrm{f}, \mathrm{h}}$ \\
\hline 19 & $22.16 \pm 0.644^{\mathrm{c}, \mathrm{i}}$ & $23.70 \pm 1.29^{c, i}$ \\
\hline 20 & $2.41 \pm 0.823^{\mathrm{b}, \mathrm{d}, \mathrm{g}, \mathrm{j}}$ & $8.34 \pm 1.12^{\mathrm{a}, \mathrm{e}, \mathrm{f}, \mathrm{h}, \mathrm{j}}$ \\
\hline 21 & $4.53 \pm 1.065^{\mathrm{b}, \mathrm{d}, \mathrm{e}, \mathrm{g}, \mathrm{j}, \mathrm{k}}$ & $4.96 \pm 0.359^{\mathrm{a}, \mathrm{b}, \mathrm{d}, \mathrm{e}, \mathrm{g}, \mathrm{k}}$ \\
\hline 22 & $5.71 \pm 0.453^{\mathrm{a}, \mathrm{b}, \mathrm{e}, \mathrm{f}, \mathrm{h}, \mathrm{k}, \mathrm{l}}$ & $13.89 \pm 1.373^{1}$ \\
\hline 23 & $8.68 \pm 0.007^{\mathrm{a}, \mathrm{e}, \mathrm{f}, \mathrm{h}, \mathrm{m}}$ & $19.27 \pm 0.995^{\mathrm{m}}$ \\
\hline 24 & $4.72 \pm 0.091^{\mathrm{b}, \mathrm{d}, \mathrm{e}, \mathrm{j}, \mathrm{k}, \mathrm{l}, \mathrm{n}}$ & $7.66 \pm 0.777^{e, f, h, j, k, o, o}$ \\
\hline 26 & $8.10 \pm 0.176^{\mathrm{a}, \mathrm{e}, \mathrm{f}, \mathrm{h}, \mathrm{l}, \mathrm{m}, \mathrm{o}}$ & $11.05 \pm 0.601^{e, f, h, j, k, p}$ \\
\hline 27 & $7.90 \pm 0.776^{\mathrm{a}, \mathrm{e}, \mathrm{f}, \mathrm{h}, \mathrm{l}, \mathrm{m}, \mathrm{o}, \mathrm{p}}$ & $8.43 \pm 0.243^{\mathrm{a}, \mathrm{e}, \mathrm{f}, \mathrm{h}, \mathrm{j}, \mathrm{o}, \mathrm{p}, \mathrm{q}}$ \\
\hline 28 & $3.67 \pm 0.264^{\mathrm{b}, \mathrm{d,g}, \mathrm{g}, \mathrm{l}, \mathrm{n}, \mathrm{n}, \mathrm{q}}$ & $4.15 \pm 0.567^{\mathrm{b}, \mathrm{d}, \mathrm{g}, \mathrm{k}, \mathrm{r}}$ \\
\hline
\end{tabular}

Different letters were used to compare the significance between compounds at the same time ( $p<0.05$ according to ANOVA followed by Tukey's post-test).

The results in Table 2 show that the propargylated derivative $\mathbf{2} \mathbf{b}$ presented superior antioxidant activity (almost 5.8-fold higher) than $\mathbf{2 a}$. This difference can be rationalized by the fact that derivative $\mathbf{2 b}$ still has a free phenolic hydroxyl group in its structure, while these groups in $\mathbf{2 a}$ were both propargylated. Rice-Evans et al. ${ }^{40}$ reported that the presence of free phenolic hydroxyl groups contributes to the antioxidant activity. The presence of these groups at the 3' and 4' positions of luteolin, a naturally-occurring flavonoid, contributes about $25 \%$ to the antioxidant activity, as described by the authors, presenting a TEAC value of $2.1 \pm 0.05 \mathrm{mmol} \mathrm{L}^{-1}$. When the hydroxyl group was absent at the 3' position, the TEAC value decreased to approximately $1.45 \pm 0.08 \mathrm{mmol} \mathrm{L}^{-1} \cdot{ }^{40}$

The presence of the chelatogenic hydroxyl group in the 2,4-dihydroxybenzophenone derivatives plays an important role in the antioxidant activity. However, only the presence of free hydroxyl group does not necessarily assure significant antioxidant activity, since $\mathbf{1 b}$ and most triazole derivatives of $\mathbf{2 b}$ showed lower TEAC values compared to $\mathbf{2 b}$.

It should be mentioned that the introduction of the triazole fragments into the benzophenone framework, in most cases, did not positively influence the antioxidant 
activity. However, triazolic derivative $\mathbf{1 9}$ was the only compound that showed no statistical difference when compared to $\mathbf{2 b}$, considering both experimental times.

Comparing derivatives that have the same benzyl substituent group, we noticed that the presence of the para-iodine benzyl group influenced antioxidant activity to the same degree, with derivatives $\mathbf{8}$ and $\mathbf{2 7}$ presenting no statistical difference. In contrast, derivatives containing fluorine showed significant differences in their TEAC values. Considering the 4,4'-dihydroxybenzophenone triazole derivatives bearing fluorine, compound $\mathbf{1 3}$ was more reactive towards DPPH than $\mathbf{5}$, indicating that the presence of two fluorine atoms favors the activity. The 2,4'-dihydroxybenzophenone triazole derivative $\mathbf{2 4}$, presenting two fluorine atoms, showed 62\% (after two hours) and $24 \%$ (after four hours) reduction in TEAC value as compared to $\mathbf{1 3}$. The compound $\mathbf{2 6}$, a derivative that also has fluorine atoms in its structure, presented a better antioxidant effect than $\mathbf{1 7}$.

Compounds 20, 21, 22, 24, and 28, which are derivatives of $\mathbf{2 b}$, showed lower TEAC values after two hours when compared to 1b. However, 20, 22, and 24 increased their antioxidant activities by approximately 246,143 , and $62 \%$, respectively, after two more hours of reaction.

The low values of TEAC for the 2,4-dihydroxybenzophenone derivatives compared to those reported in the literature ${ }^{41,42}$ for phenolic compounds are directly associated with the formation of intramolecular hydrogen bonds between the neighboring $\mathrm{OH}$ and carbonyl groups of benzophenone, which leaves hydrogen less available to be donated to the DPPH radical. Thus, the antioxidant activity is directly related to the hydrogen transfer capacity, and the dissociation of $\mathrm{O}-\mathrm{H}$ bond is an important factor in determining the efficacy of an antioxidant. The weaker the $\mathrm{O}-\mathrm{H}$ bond, the faster the reaction with $\mathrm{DPPH}$ free radical.

The derivatives $\mathbf{1 3}, \mathbf{2 0}, \mathbf{2 2}, \mathbf{2 3}, \mathbf{2 4}$, and 26 showed statistical differences in TEAC values calculated after two and four hours of reaction (Figure 2). These results suggest that for these compounds, the hydrogen transfer reaction to the DPPH radical occurs following slow kinetics. For example, comparing compounds $\mathbf{2 3}$ and $\mathbf{2 b}$ (Table 2), it can be noticed that after $4 \mathrm{~h}$ of reaction the TEAC value of $\mathbf{2 3}$ is about $20 \%$ smaller than the TEAC value of $\mathbf{2 b}$. Using the DPPH method, Brand-Williams et al.$^{43}$ evaluated the antioxidant activity of several phenolic compounds. They also found remarkable differences concerning the kinetics of the reactions between DPPH and compounds under evaluation. The phenolic compounds ascorbic acid, isoascorbic acid, and isoeugenol achieved a steady-state quickly. ${ }^{43}$

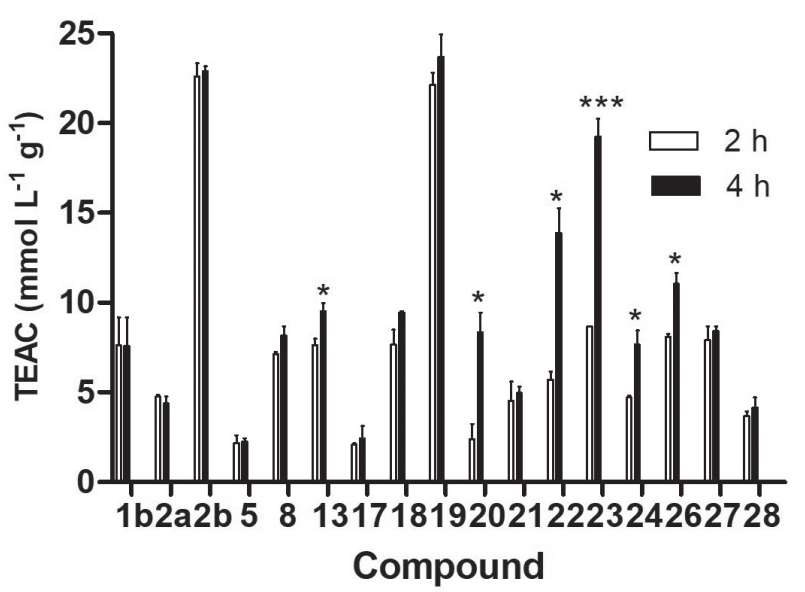

Figure 2. Influence of the reaction time on TEAC values for 1,2,3-triazole benzophenone derivatives and compounds $\mathbf{1 b}, \mathbf{2} \mathbf{a}$, and $\mathbf{2 b}$. $* * * p<0.005$ and $* p<0.05$ according to $t$-test.

In the next step, the cytotoxicity of the 1,2,3-triazole derivatives (4-18 and 19-29) was evaluated against three human tumor cell lines A549 (lung carcinoma), MCF-7 (breast carcinoma), and HT-144 (metastatic melanoma). The benzophenones used in chemical design (1a and $\mathbf{1 b})$ and precursors of synthesized substances ( $2 \mathbf{a}$ and $\mathbf{2 b}$ ) were included in the cell viability assays.

\section{Cytotoxicity evaluation}

Cell viability was assessed after $48 \mathrm{~h}$ treatment and the substances were screened at $40 \mu \mathrm{mol} \mathrm{L}^{-1}$. The viability rates were not significantly altered in cell cultures treated with the substances 1a, 2a, and 4-18 compared to control cultures (data not shown), indicating that these compounds had no cytotoxic activity on tested tumor cell lines at $40 \mu \mathrm{mol} \mathrm{L}{ }^{-1}$. By contrast, triazole derivatives obtained from $\mathbf{1 b}$ displayed cytotoxic activity against tumor cells when assayed at the same conditions $\left(40 \mu \mathrm{mol} \mathrm{L}^{-1}\right.$ for $48 \mathrm{~h}$ ). The viability rates observed for MCF-7 cultures treated with substances 19-21, 24, and 26 were lower compared to $\mathbf{1 b}$. All these substances were more efficient in reducing cell viability $(p<0.05)$ than $\mathbf{1 b}$, and substances 19 and $\mathbf{2 6}$ were the most actives (Figure 3). In A549 cultures, there was a significant reduction in cell viability in samples treated with 19-21, 23, 24, 26, and 28. The substances 19, 21, and $\mathbf{2 4}$ displayed higher cytotoxicity on A549 cells than other compounds, and their effects were much more pronounced than $\mathbf{1 b}$ (Figure 3). Regarding HT-144 cells, reduced viability rates were observed in almost all treated samples in comparison to controls. Only substances $\mathbf{2 2}$ and $\mathbf{2 6}$ had no cytotoxic activity on melanoma cells. The substances 19, 20, and 24 were the most active compared to other derivatives of the series or $\mathbf{1 b}$ (Figure 3). 

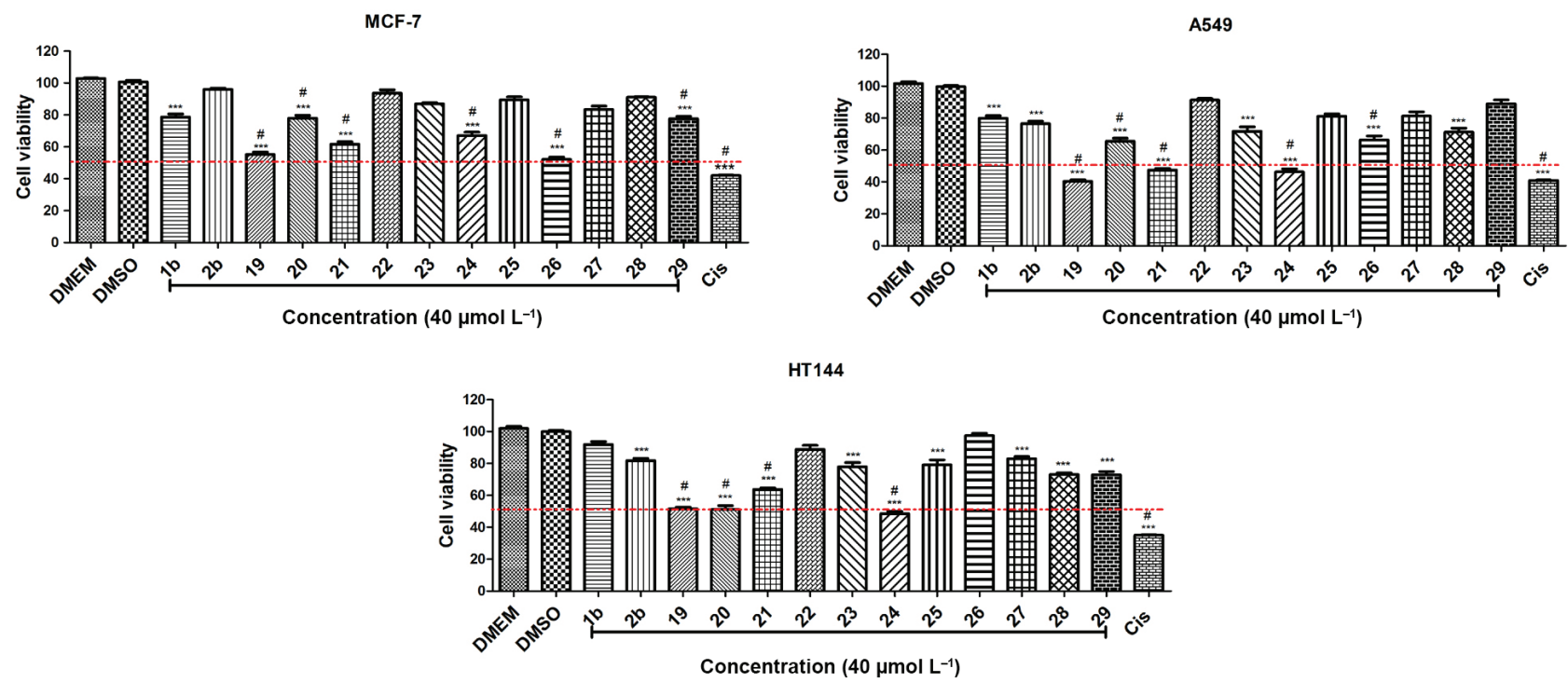

Figure 3. Cell viability determined by (3-(4,5-dimethylthiazol-2-yl)-5-(3-carboxymethoxyphenyl)-2-(4-sulfophenyl)-2H-tetrazolium) (MTS) assay after $48 \mathrm{~h}$ of treatment with $\mathbf{1 b}, \mathbf{2 b}$ and triazoles 19-29. ***Significant difference $(p<0.001)$ from DMSO group according to ANOVA followed by Dunnet's post-test. \#: significant difference $(p<0.05)$ from precursor $(\mathbf{2 b})$ according to ANOVA followed by Dunnet's post-test. DMSO and DMEM are the negative controls; cisplatin is the positive control.

We further determined the $\mathrm{IC}_{50}$ values (concentration capable of inhibiting $50 \%$ of cell viability) for the most active compounds (Table 3). Both assayed substances $\mathbf{1 9}$ and 26 against MCF-7 cells displayed $\mathrm{IC}_{50}$ values lower than those found for cisplatin, a powerful cytotoxic agent and used as positive control. Besides, these substances showed a better selectivity profile compared to cisplatin that presented higher cytotoxicity toward normal cells than 19 and 26. These findings are very promising considering that breast cancer is the second most prevalent cancer worldwide. Despite advances in diagnostic and treatment modalities, breast cancer remains the major cause of cancer deaths among women. ${ }^{44}$ The high mortality rate for breast cancer is closely associated with complexity of the disease and intrinsic or acquired resistance to available drugs. ${ }^{45}$ Further studies will be addressed to evaluate the underlying mechanism related to cytotoxic activity of the substances 19 and 26 on estrogen-positive MCF-7 breast cancer cells.
Even though the $\mathrm{IC}_{50}$ values found for substances 19, 21 and $\mathbf{2 4}$ on A549 cells have been upward to that observed for cisplatin, these compounds significantly reduced viability in A549 cultures compared to control groups. Furthermore, these substances were much less cytotoxic against normal cells (CCD-1059Sk) than tumor cells. These findings suggest that these triazoles might be useful in future clinical application, supporting further studies to evaluate better their antitumor activity on lung adenocarcinoma cells. Platinum-based drugs are commonly used to treat lung cancer patients; however, these substances are highly toxic and trigger several side-effects including nephrotoxicity. Indeed, carboplatin, an analogue of cisplatin, were developed especially to minimize toxic effects caused by the cisplatin. ${ }^{46}$ In the present study we found that triazole derivatives 19, 21 and 24 were effective to reduce cell viability in adenocarcinoma A549 cells and further studies will be conducted to evaluate the mechanism of action associated

Table 3. $\mathrm{IC}_{50}$ values determined from MTS assay. Cell cultures were treated with different substances for $48 \mathrm{~h}$

\begin{tabular}{lcccc}
\hline \multirow{2}{*}{ Compound } & \multicolumn{3}{c}{$\left.\mathrm{IC}_{50} /(\mu \mathrm{mol} \mathrm{L})^{-1}\right)$} \\
\cline { 2 - 5 } & $\mathrm{A} 549$ & HT-144 & MCF-7 & CCD-1059Sk $^{\mathrm{a}}$ \\
\hline $\mathbf{1 9}$ & $37.58 \pm 1.09$ & $53.98 \pm 2.14$ & $50.43 \pm 1.49$ & $>200$ \\
$\mathbf{2 0}$ & - & $39.51 \pm 1.30$ & - & $199.20 \pm 14.09$ \\
$\mathbf{2 4}$ & $30.42 \pm 1.01$ & - & - & $\mathrm{nd}$ \\
$\mathbf{2 6}$ & $46.75 \pm 1.25$ & $57.18 \pm 1.84$ & $63.47 \pm 1.75$ & $\mathrm{nd}$ \\
Cisplatin $^{\mathrm{b}}$ & - & - & $75.73 \pm 1.43$ & $71.23 \pm 4.25$ \\
\hline
\end{tabular}

${ }^{a}$ Non-tumor cell line; ${ }^{b}$ cisplatin was used as a positive control. $\mathrm{IC}_{50}$ : concentration capable of inhibiting $50 \%$ of cell viability; A549: lung carcinoma; MCF-7: breast carcinoma; HT-144: metastatic melanoma; nd: not determined once reduction in cell viability was not sufficient to determine $\mathrm{IC}_{50}$ values. 
with cytotoxic activity of these substances on A549 cells and their antitumor potential in pre-clinical studies.

We showed that the substances 19, 20 and 24 significantly reduced viability rate in melanoma cultures, a type of skin cancer highly aggressive. ${ }^{47}$ In view of that, we decided to further explore the effects of these substances on HT-144 cells that harbor BRAF V600E mutation, ${ }^{48,49}$ a punctual mutation frequently found in melanoma. $B R A F$ gene encodes rapidly accelerated fibrosarcoma (RAF) protein, a member of mitogen-activated protein kinase (MAPK) family. RAF/MEK/ERK (RAF/mitogen-activated protein/extracellular-signal-regulated kinase) signaling pathway regulates important biological processes including proliferation and survival. ${ }^{50,51}$ BRAF mutation in melanoma is direct or indirectly associated to ERK and protein kinase B (AKT) hyper activation leading to uncontrolled cell proliferation, survival and tumor progression. ${ }^{52,53}$

We performed cell cycle analysis to investigate whether the viability reduction previously observed in HT-144 cell cultures treated with substances 19, 20 and $\mathbf{2 4}$ could be associated to their ability of inhibiting cell cycle progression and/or to induce cell death. Increased G0/G1 populations were observed in all cell cultures treated (Figure 4). Besides, there was a significant reduction in G2/M populations in samples treated with substances 19 and 24. Taken together, the data indicate that these compounds inhibited cell cycle progression of HT-144 cells at G1 phase. G1/S transition is positively regulated by cyclin-dependent kinases (CDKs) 4/6 and 2, which are activated respectively by cyclin D and cyclin E. ${ }^{54}$ As mentioned before, the high proliferative ability of melanoma cells is closely associated to ERK activation that, in turn, induces high expression of cyclin D1. ${ }^{55}$

We demonstrated, for the first time, that hydroxylated benzophenone derivatives containing 1,2,3-triazole fragments inhibit cell cycle arrest at G1 in melanoma cells. It has been reported ${ }^{56}$ that cycle arrest at G1/S transition in MCF-7 cells was induced by 7-hydroxycoumarin triazoles. Similarly, tetrahydro-[1,2,4]triazolo[3,4-a]isoquinoline chalcones promoted cell cycle arrest of MCF-7 cells at G1 phase. Begnini et al. ${ }^{57}$ also observed cell cycle arrest when treated triple negative breast cancer cells (MDA-MB-231) with 7-chloroquinoline-1,2,3-triazoyl carboxamides. A recent study ${ }^{58}$ demonstrated that 1,2,3-triazole derivatives of hydnocarpic acid induced cell cycle arrest at G1/S transition in non-small cell lung cancer A549 cells.

In addition to its ability to inhibit cell cycle progression, substance 19 induced cell death as demonstrated by increasing of the sub-G1 population. Interestingly, this same substance displayed a significant antioxidant activity in DPPH assay. Many studies ${ }^{59-61}$ have demonstrated that
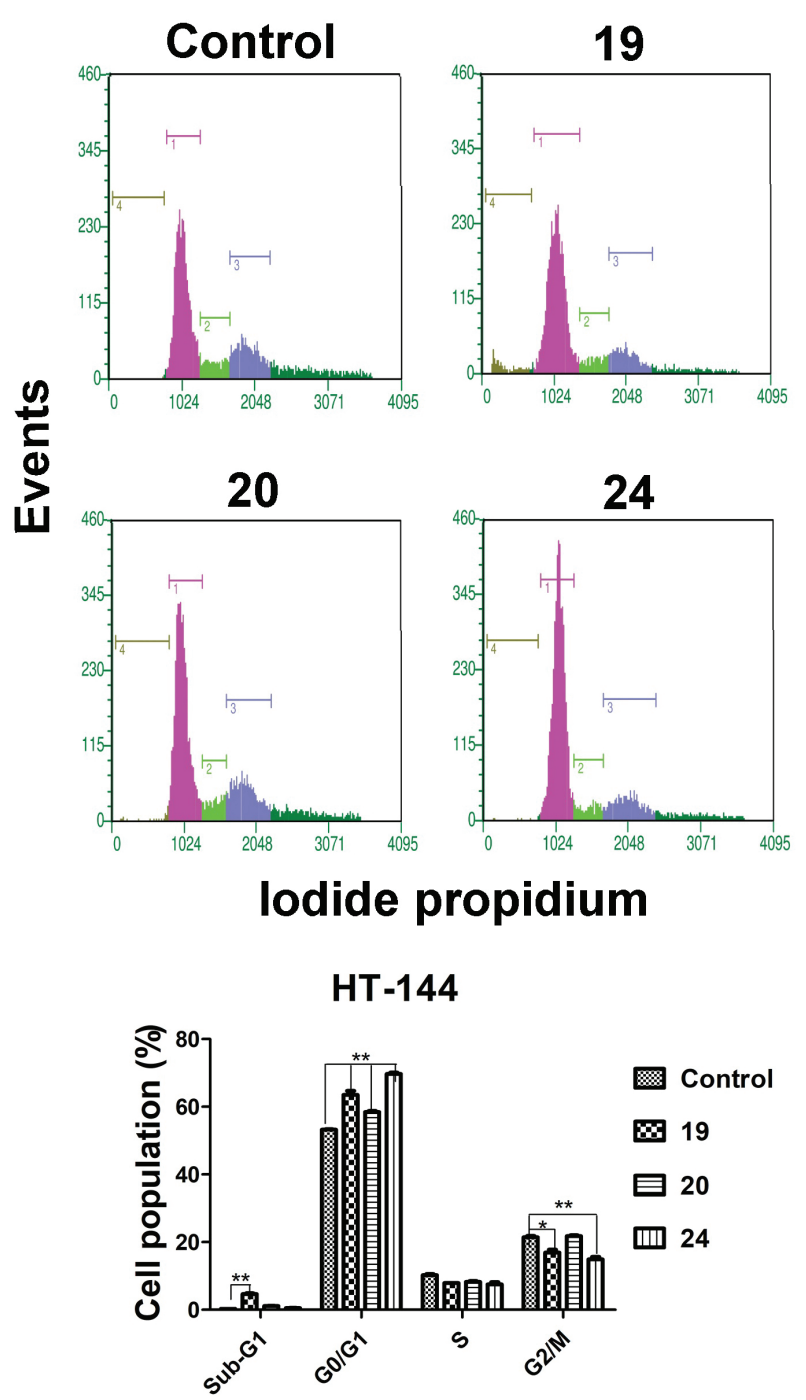

Figure 4. Representative histograms obtained by flow cytometry and quantitative analysis. HT-144 cell cultures were treated for $48 \mathrm{~h}$ with different substances at $40 \mu \mathrm{mol} \mathrm{L} \mathrm{L}^{-1}$. The different cell populations are shown in brown (SubG1); pink (G0/G1); green (S); blue (G2/M).

antioxidant agents may be useful to prevent tumorigenesis. On the other hand, several studies ${ }^{62}$ have showed that many phytochemical substances with antioxidant property inhibit proliferation and induce cell death in cancer cells by increasing oxidative stress. The metabolic conditions of cancer cells are different from normal cells. Cancer cells have a high metabolism and produce elevated levels of reactive oxygen species (ROS), and therefore cancer cells rely on a robust endogenous antioxidant system to maintain ROS levels below the cytotoxic threshold. ${ }^{59}$ Antioxidant agents may interfere with metabolic-redox in cancer cell and consequently contribute for inducing cancer cell death. ${ }^{63}$

Our findings showed that 1,2,3-triazole-benzophenone derivatives have antitumor potential and support further studies to evaluate deeply their molecular targets in HT-144 cells. These substances might turn out to be help 
in a future clinical application for melanoma treatment which therapeutic proposals are limited due to intrinsic and acquired drug resistance.

\section{Conclusions}

A series of twenty-six 1,2,3-triazole-benzophenone derivatives were obtained in two steps from commercially available 4,4'-dihydroxybenzophenone and 2,4-dihydroxybenzophenone. The 1,2,3-triazoles were obtained with yields ranging from 35 to $95 \%$. The compounds were evaluated with regard to their photoprotective, antioxidant, and cytotoxicity in vitro activities. The 1,2,3-triazole derivatives showed efficacy comparable to the commercial product BP-3 at $0.2 \mu \mathrm{g} \mathrm{mL} \mathrm{L}^{-1}$. The derivatives $\mathbf{2 b}$ and $\mathbf{1 9}$ displayed a significant antioxidant activity. Moreover, the substance 19 efficiently reduced viability in tumor cell lines (A549, MCF-7, and HT-144) and did not show significant cytotoxicity on a noncancerous cell line (CCD-1059Sk). We also demonstrated that derivatives 19, 20, and $\mathbf{2 4}$ induced cell cycle arrest at G1 in HT-144 cells. It is important to highlight that at $0.2 \mu \mathrm{g} \mathrm{mL} \mathrm{m}^{-1}$, concentration used to photoprotective assays, represents a no-cytotoxic concentration. Thus, taken together, the data show that 1,2,3-triazole derivatives obtained from hydroxybenzophenones may be considered promising prototypes for the development of new drugs with the dual antioxidant and anticancer effect.

\section{Experimental}

\section{Generalities}

All reagents and solvents were purchased from SigmaAldrich (Saint Louis, MO, USA) and Vetec (Duque de Caxias, RJ, Brazil) and were used without further purification. Analytical thin layer chromatography (TLC) analysis was conducted on aluminum-backed precoated silica gel plates (Macherey-Nagel DC-Fertigfolien ALUGRAM ${ }^{\otimes}$ Xtra SIL G/UV254, Düren, Germany) using different solvent systems. TLC plates were visualized using UV light $(\lambda=254 \mathrm{~nm})$ and potassium permanganate solution.

Flash column chromatography was performed with silica gel (70-230 mesh, Macherey-Nagel, Düren, Germany). ${ }^{1} \mathrm{H}$ and ${ }^{13} \mathrm{C}$ NMR spectra were recorded on a Varian Mercury 300 instrument (Varian, Palo Alto, CA, USA) at 300 and $75 \mathrm{MHz}$, respectively, using $\mathrm{CDCl}_{3}$ or dimethyl sulfoxide (DMSO- $d_{6}$ ) as solvents.

${ }^{1} \mathrm{H}$ NMR data are presented as follows: chemical shift $(\delta)$ in ppm, multiplicity, the number of hydrogens, and coupling constant $(J)$ values in hertz $(\mathrm{Hz})$. Multiplicities are shown as the following abbreviations: s (singlet), $d$ (doublet), dd (doublet of doublets), $t$ (triplet), $m$ (multiplet). For fluorine-containing derivatives, the multiplicity of some carbon signals are described along with $J$ values in hertz. Melting points (mp) were recorded on the MQAPF-302 equipment (Microquímica Equipamentos, Palhoça, SC, Brazil) and were not corrected. Attenuated total reflectance Fourier transform infrared (ATR-FTIR) spectra were obtained using Varian 660-IR (Varian, Palo Alto, CA, USA) equipped with GladiATR scanning from 4000 to $500 \mathrm{~cm}^{-1}$. The HRMS analysis was performed using the Impact II Brucker UHR-QqTOF (ultra-high resolution qq time of flight) mass spectrometry (Bruker Daltonics Corporation, Bremen, Germany). The acquisition software used was Otof Control and Hystar software package (Bruker Daltonics) and equipped with an electrospray source operating in negative ionization mode.

\section{Synthesis}

Synthesis of bis(4-(prop-2-yn-1-yloxy))benzophenone (2a) In a previous study, ${ }^{32}$ we reported the production of $\mathbf{2 a}$. Potassium carbonate $(3.87 \mathrm{~g}, 28.0 \mathrm{mmol})$ and propargyl bromide $(1.50 \mathrm{~mL})$ were added to a stirred solution of 4,4'-dihydroxybenzophenone $(1.50 \mathrm{~g}, 7.00 \mathrm{mmol})$ in acetone $(50 \mathrm{~mL})$. The reaction mixture was refluxed for $24 \mathrm{~h}$. The reaction was quenched with ice-water $/ \mathrm{CH}_{2} \mathrm{Cl}_{2}$ (dichloromethane (DCM)). The phases were separated, and the aqueous layer was extracted with ethyl acetate $(3 \times 20 \mathrm{~mL})$. The extracts were combined, and the resulting organic layer was washed with brine, dried over anhydrous sodium sulfate, and concentrated under reduced pressure to provide crude compound 2a. After purification by silica gel flash column chromatography, eluted with ethyl acetateDCM-hexane 3:1:3 v/v, compound 2a was obtained as a yellow solid with $83 \%$ yield $(1.68 \mathrm{~g}, 5.79 \mathrm{mmol})$. The structure of compound 2a is supported by the following data.

TLC: $\mathrm{R}_{\mathrm{f}}=0.60$ (ethyl acetate-DCM-hexane $3: 1: 3 \mathrm{v} / \mathrm{v}$ ); mp 91.3-92.2 ${ }^{\circ} \mathrm{C}$; IR (ATR) $v / \mathrm{cm}^{-1} 3219,2971,2112$, $1578,1558,1503,1267 ;{ }^{1} \mathrm{H}$ NMR $\left(300 \mathrm{MHz}, \mathrm{CDCl}_{3}\right) \delta 2.57$ (s, 2H), 4.77 (s, 4H), 7.05 (d, 4H, J $8.3 \mathrm{~Hz}), 7.80$ (d, 4H, $J 8.3 \mathrm{~Hz}) ;{ }^{13} \mathrm{C} \mathrm{NMR}\left(75 \mathrm{MHz}, \mathrm{CDCl}_{3}\right) \delta 55.9,76.1,76.6$, 114.4, 131.3, 132.2, 160.7, 194.3; HRMS $m / z$, calculated for $\mathrm{C}_{19} \mathrm{H}_{15} \mathrm{O}_{3}[\mathrm{M}+\mathrm{H}]^{+}$: 291.1016, found: 291.1016.

Synthesis of (2-hydroxy-4-(prop-2-yn-1-yloxy))benzophenone (2b)

Potassium carbonate ( $2.58 \mathrm{~g}, 18.7 \mathrm{mmol})$ and propargyl bromide $(1.00 \mathrm{~mL})$ were added to a stirred solution of 
2,4-dihydroxybenzophenone $(1.50 \mathrm{~g}, 7.00 \mathrm{mmol})$ in acetone $(50 \mathrm{~mL})$. The reaction mixture was refluxed for $24 \mathrm{~h}$. After this time, the reaction was quenched with icewater/ $\mathrm{CH}_{2} \mathrm{Cl}_{2}$. The phases were separated, and the aqueous layer was extracted with ethyl acetate $(3 \times 20 \mathrm{~mL})$. The extracts were combined, and the resulting organic layer was washed with brine, dried over anhydrous sodium sulfate, and concentrated under reduced pressure to provide crude compound $\mathbf{2 b}$. After purification by silica gel flash column chromatography, eluted with hexane-ethyl acetate $2: 1 \mathrm{v} / \mathrm{v}$, compound $\mathbf{2 b}$ was obtained as a yellow solid with $61 \%$ yield (1.44 g, $5.69 \mathrm{mmol})$. The structure of compound $\mathbf{2 b}$ is supported by the following data.

TLC: $\mathrm{R}_{\mathrm{f}}=0.79$ (ethyl acetate-DCM-hexane $3: 1: 3 \mathrm{v} / \mathrm{v}$ ); $\mathrm{mp} 70.8-71.9^{\circ} \mathrm{C}$; IR (ATR) $v / \mathrm{cm}^{-1} 3301,3284,2120$, 1620, 1594, 1573, 1502, 1444, 1381, 1343, 1278, 1249, 1221, 1167, 1111, 1019, 909, 693; ${ }^{1} \mathrm{H}$ NMR (300 MHz, $\left.\mathrm{CDCl}_{3}\right) \delta 2.58(\mathrm{t}, 1 \mathrm{H}, J 2.4 \mathrm{~Hz}), 4.74(\mathrm{~d}, 2 \mathrm{H}, J 2.1 \mathrm{~Hz}), 6.48$ $\left(\mathrm{dd}, 1 \mathrm{H}, J_{1} 2.7 \mathrm{~Hz}\right.$ and $\left.J_{2} 9.0 \mathrm{~Hz}\right), 6.61(\mathrm{~d}, 1 \mathrm{H}, J 2.4 \mathrm{~Hz})$, $7.48(\mathrm{dd}, 2 \mathrm{H}, J 1.5,8.4 \mathrm{~Hz}), 7.52(\mathrm{~s}, 1 \mathrm{H}), 7.56(\mathrm{~d}, 1 \mathrm{H}$, $J 6.3 \mathrm{~Hz}), 7.64$ (dd, 2H, J 1.5, $8.4 \mathrm{~Hz}), 12.63$ (s, 1H); ${ }^{13} \mathrm{C}$ NMR $\left(75 \mathrm{MHz}, \mathrm{CDCl}_{3}\right) \delta 55.9,76.4,102.3,107.6$, 113.7, 128.3, 128.8, 131.6, 135.3, 138.1, 163.9, 166.0, 200.1; HRMS $\mathrm{m} / \mathrm{z}$, calculated for $\mathrm{C}_{16} \mathrm{H}_{13} \mathrm{O}_{3}[\mathrm{M}+\mathrm{H}]^{+}$: 253.0859, found: 253.0855 .

\section{Synthesis of target compounds 4-18}

The synthesis of triazoles was performed according to our previous study. ${ }^{32}$ A round bottom flask $(50 \mathrm{~mL})$ was charged with bis(4-(prop-2-yn-1-yloxy))benzophenone (2) (1.00 equiv.), benzyl azide (4.00 equiv.), sodium ascorbate ( 0.800 equiv.), dichloromethane $(1.50 \mathrm{~mL})$, distilled water $(1.50 \mathrm{~mL})$, and $\mathrm{CuSO}_{4} \cdot 5 \mathrm{H}_{2} \mathrm{O}(0.400$ equiv.). The resulting reaction mixture was vigorously stirred at room temperature for $6 \mathrm{~h}$ and the progress of the reaction was monitored by TLC analysis. The reaction was quenched by addition of saturated sodium bicarbonate aqueous solution $(15 \mathrm{~mL})$. The layers were separated, and the aqueous phase was extracted with dichloromethane $(3 \times 20 \mathrm{~mL})$. The organic extracts were combined, and the resulting organic layer was dried over anhydrous sodium sulfate, filtered, and concentrated under reduced pressure to provide crude compounds. Compounds 4-18 were purified by silica gel flash column chromatography eluted with ethyl acetateDCM-hexane 3:1:3 v/v. Structures of the synthesized compounds are supported by the following data.

Bis(4-(1-benzyl-1 H-1,2,3-triazol-4-yl)methoxy)benzophenone (4)

Yield: 66\% (0.190 g, $0.269 \mathrm{mmol})$; white solid; mp
144-145 ${ }^{\circ} \mathrm{C}$; TLC: $\mathrm{R}_{\mathrm{f}}=0.18$ (ethyl acetate-DCM-hexane $3: 1: 3 \mathrm{v} / \mathrm{v}$ ); IR (ATR) $\mathrm{v} / \mathrm{cm}^{-1} 3091,2159,2017,1639,1559$, 1506,$1247 ;{ }^{1} \mathrm{H}$ NMR $\left(300 \mathrm{MHz}, \mathrm{CDCl}_{3}\right) \delta 5.25(\mathrm{~s}, 2 \mathrm{H}), 5.54$ (s, 4H), 7.02 (d, 4H, J 8.4 Hz), 7.26-7.38 (m, 10H), 7.56 (s, $2 \mathrm{H}), 7.75(\mathrm{~d}, 4 \mathrm{H}, J 8.4 \mathrm{~Hz}) ;{ }^{13} \mathrm{C} \mathrm{NMR}\left(75 \mathrm{MHz}, \mathrm{CDCl}_{3}\right) \delta$ $54.3,62.1,114.2,122.8,128.1,128.9,129.2,131.1,132.2$, 134.2, 143.9, 161.4, 194.3; HRMS $\mathrm{m} / \mathrm{z}$, calculated for $\mathrm{C}_{33} \mathrm{H}_{29} \mathrm{~N}_{6} \mathrm{O}_{3}[\mathrm{M}+\mathrm{H}]^{+}:$557.2296, found: 557.2322.

Bis(4-(1-(4-fluorobenzyl)-1H-1,2,3-triazol-4-yl)methoxy) benzophenone (5)

Yield: $65 \%$ (0.190 g, $0.303 \mathrm{mmol})$; white solid; mp 139-140 ${ }^{\circ} \mathrm{C}$; TLC: $\mathrm{R}_{\mathrm{f}}=0.10$ (ethyl acetate-DCM-hexane 3:1:3 v/v); IR (ATR) v / $\mathrm{cm}^{-1} 3137,1639,1599,1225$; ${ }^{1} \mathrm{H}$ NMR $\left(300 \mathrm{MHz}, \mathrm{CDCl}_{3}\right) \delta 5.25(\mathrm{~s}, 4 \mathrm{H}), 5.51(\mathrm{~s}, 4 \mathrm{H})$, $7.03(\mathrm{t}, 4 \mathrm{H}, J 8.7 \mathrm{~Hz}), 7.09$ (s, 4H), 7.25-7.30 (m, 4H), 7.56 (s, 2H), $7.74(\mathrm{~d}, 4 \mathrm{H}, J 8.7 \mathrm{~Hz}) ;{ }^{13} \mathrm{C} \mathrm{NMR}\left(75 \mathrm{MHz}, \mathrm{CDCl}_{3}\right)$ $\delta 53.5,62.1,114.2,116.2(\mathrm{~d}, J 21.5 \mathrm{~Hz}), 122.7,130.2(\mathrm{~d}$, $J 3.2 \mathrm{~Hz}$ ), 130.4 (d, J 8.5 Hz), 131.0, 132.2, 144.0, 161.4, 162.9 (q, $J 246.9 \mathrm{~Hz}$ ), 194.3; HRMS $\mathrm{m} / \mathrm{z}$, calculated for $\mathrm{C}_{33} \mathrm{H}_{27} \mathrm{~F}_{2} \mathrm{~N}_{6} \mathrm{O}_{3}[\mathrm{M}+\mathrm{H}]^{+}$: 593.2107, found: 593.2109.

Bis(4-(1-(4-chlorobenzyl)-1H-1,2,3-triazol-4-yl)methoxy) benzophenone (6)

Yield: $53 \%$ (0.170 g, $0.272 \mathrm{mmol})$; white solid; mp 163-164 ${ }^{\circ} \mathrm{C}$; TLC: $\mathrm{R}_{\mathrm{f}}=0.10$ (ethyl acetate-DCM-hexane 3:1:3 v/v); IR (ATR) v / cm ${ }^{-1} 3158,2935,2364,1978,1638$, 1600, 1249; ${ }^{1} \mathrm{H}$ NMR (300 MHz, $\left.\mathrm{CDCl}_{3}\right) \delta 5.25$ (s, 4H), 5.51 (s, 4H), 7.02 (dd, 4H, J 9.0, $2.3 \mathrm{~Hz}), 7.22(\mathrm{dd}, 4 \mathrm{H}$, $J$ 8.7, 2.2 Hz), 7.35 (dd, 4H, J 8.7, $2.2 \mathrm{~Hz}), 7.57$ (s, 2H), 7.77 (dd, 4H, $J$ 9.0, $2.3 \mathrm{~Hz}) ;{ }^{13} \mathrm{C} \mathrm{NMR}\left(75 \mathrm{MHz}, \mathrm{CDCl}_{3}\right.$ ) $\delta$ 53.6, 62.0, 114.2, 122.7, 129.4, 129.5, 131.1, 132.2, 132.8, 134.9, 144.1, 161.4, 194.3; HRMS $m / z$, calculated for $\mathrm{C}_{33} \mathrm{H}_{27} \mathrm{Cl}_{2} \mathrm{~N}_{6} \mathrm{O}_{3}[\mathrm{M}+\mathrm{H}]^{+}$: 625.1516 , found: 625.1513 .

Bis(4-(1-(4-bromobenzyl)-1H-1,2,3-triazol-4-yl)methoxy) benzophenone (7)

Yield: $71 \%$ (0.248 g, $0.347 \mathrm{mmol})$; white solid; mp 182-183 ${ }^{\circ} \mathrm{C}$; TLC: $\mathrm{R}_{\mathrm{f}}=0.13$ (ethyl acetate-DCM-hexane 3:1:3 v/v); IR (ATR) v / cm ${ }^{-1} 3158,2935,2360,1982,1638$, 1600,$1225 ;{ }^{1} \mathrm{H}$ NMR $\left(300 \mathrm{MHz}, \mathrm{DMSO}-d_{6}\right) \delta 5.24(\mathrm{~s}, 4 \mathrm{H})$, 5.60 (s. 4H), 7.16 (d, 4H, J 8.7 Hz), 7.27 (d, 4H, J 8.1 Hz), 7.57 (d, 4H, J 8.1 Hz), 7.57 (s, 2H), 7.69 (d, J 8.7 Hz); ${ }^{13} \mathrm{C}$ NMR $\left(75 \mathrm{MHz}\right.$, DMSO- $\left.d_{6}\right) \delta 53.6,62.1,121.9,125.4$, $130.6,130.7,132.2,132.3,135.8,143.0,144.2,161.7$, 194.6; HRMS $m / z$, calculated for $\mathrm{C}_{33} \mathrm{H}_{27} \mathrm{Br}_{2} \mathrm{~N}_{6} \mathrm{O}_{3}[\mathrm{M}+\mathrm{H}]^{+}$: 713.0506, found: 713.0515 .

Bis(4-(1-(4-iodobenzyl)-1 H-1,2,3-triazol-4-yl)methoxy) benzophenone (8)

Yield: $42 \%$ (0.055 g, $0.062 \mathrm{mmol})$; white solid; mp 
190-191 ${ }^{\circ} \mathrm{C}$; TLC: $\mathrm{R}_{\mathrm{f}}=0.18$ (ethyl acetate-DCM-hexane $3: 1: 3 \mathrm{v} / \mathrm{v}$ ); IR (ATR) $\mathrm{v} / \mathrm{cm}^{-1} 3102,2163,1734,1634,1601$, 1582,1278 ; ${ }^{1} \mathrm{H}$ NMR (300 MHz, DMSO- $\left.d_{6}\right) \delta 5.25(\mathrm{~s}, 4 \mathrm{H})$, $5.58(\mathrm{~s}, 4 \mathrm{H}), 7.12(\mathrm{~d}, 4 \mathrm{H}, J 8.1 \mathrm{~Hz}), 7.17(\mathrm{~d}, 4 \mathrm{H}, J 8.6 \mathrm{~Hz})$, 7.67 (d, 4H, J 8.6 Hz), 7.74 (d, 4H, J 8.1 Hz), $8.32(\mathrm{~s}, 2 \mathrm{H})$; ${ }^{13} \mathrm{C}$ NMR (75 MHz, DMSO- $d_{6}$ ) $\delta 52.7,61.8,94.9,114.9$, 125.4, 130.6, 130.7, 132.2, 136.2, 138.0, 142.9, 161.7, 193.6; HRMS $m / z$, calculated for $\mathrm{C}_{33} \mathrm{H}_{27} \mathrm{I}_{2} \mathrm{~N}_{6} \mathrm{O}_{3}[\mathrm{M}+\mathrm{Na}]^{+}$: 809.0228, found: 809.0202.

Bis(4-(1-(2-methylbenzyl)-1H-1,2,3-triazol-4-yl)methoxy) benzophenone (9)

Yield: 55\% (0.165 g, $0.282 \mathrm{mmol}$ ); white solid; $\mathrm{mp}$ 186- $187{ }^{\circ} \mathrm{C}$; TLC: $\mathrm{R}_{\mathrm{f}}=0.32$ (ethyl acetate-DCM-hexane 3:1:3 v/v); IR (ATR) v / $\mathrm{cm}^{-1} 3099,2921,1970,1639$, 1601, 1258; ${ }^{1} \mathrm{H}$ NMR $\left(300 \mathrm{MHz}, \mathrm{CDCl}_{3}\right) \delta 2.28(\mathrm{~s}, 6 \mathrm{H})$, $5.24(\mathrm{~s}, 4 \mathrm{H}), 5.56(\mathrm{~s}, 4 \mathrm{H}), 7.02(\mathrm{~d}, 4 \mathrm{H}, J 8.4 \mathrm{~Hz}), 7.20-7.33$ (m, 8H), 7.44 (s, 2H), 7.75 (d, 4H, J 8.4 Hz); ${ }^{13} \mathrm{C}$ NMR $\left(75 \mathrm{MHz}, \mathrm{CDCl}_{3}\right) \delta 18.9,52.5,62.1,114.3,122.6,126.7$, 129.3, 129.5, 131.0, 131.1, 132.2, 136.9, 143.7, 161.4, 194.3; HRMS $m / z$, calculated for $\mathrm{C}_{35} \mathrm{H}_{33} \mathrm{~N}_{6} \mathrm{O}_{3}[\mathrm{M}+\mathrm{H}]^{+}$: 585.2609, found: 585.2609.

Bis(4-(1-(3-methylbenzyl)-1H-1,2,3-triazol-4-yl)methoxy) benzophenone (10)

Yield: $42 \%$ (0.126 g, $0.215 \mathrm{mmol})$; white solid; mp 130-131 ${ }^{\circ} \mathrm{C}$; TLC: $\mathrm{R}_{\mathrm{f}}=0.25$ (ethyl acetate-DCM-hexane 3:1:3 v/v); IR (ATR) v / $\mathrm{cm}^{-1} 3122,2944,2165,1976,1640$, 1596, 1236; ${ }^{1} \mathrm{H}$ NMR (300 MHz, $\left.\mathrm{CDCl}_{3}\right) \delta 2.34$ (s, 6H), $5.25(\mathrm{~s}, 4 \mathrm{H}), 5.50(\mathrm{~s}, 4 \mathrm{H}), 7.02(\mathrm{~d}, 4 \mathrm{H}, J 8.7 \mathrm{~Hz}), 7.06-7.09$ $(\mathrm{m}, 4 \mathrm{H}), 7.17(\mathrm{~d}, 2 \mathrm{H}, J 7.5 \mathrm{~Hz}), 7.26(\mathrm{t}, 2 \mathrm{H}, J 8.4 \mathrm{~Hz}), 7.56$ (s, 2H), $7.75(\mathrm{~d}, 4 \mathrm{H}, J 8.7 \mathrm{~Hz}) ;{ }^{13} \mathrm{C} \mathrm{NMR}\left(75 \mathrm{MHz}, \mathrm{CDCl}_{3}\right.$ ) $\delta 21.3,54.3,62.1,114.2,122.7,125.2,128.9,129.0,129.6$, 131.1, 132.2, 134.2, 139.0, 143.8, 161.4, 194.3; HRMS $\mathrm{m} / z$, calculated for $\mathrm{C}_{35} \mathrm{H}_{33} \mathrm{~N}_{6} \mathrm{O}_{3}[\mathrm{M}+\mathrm{H}]^{+}: 585.2609$, found: 585.2600 .

$\operatorname{Bis}(4-(1-(4-m e t h y l b e n z y l)-1 H-1,2,3-t r i a z o l-4-y l) m e t h o x y)$ benzophenone (11)

Yield: $59 \%$ (0.177 g, $0.302 \mathrm{mmol})$; white solid; $\mathrm{mp}$ 134-135 ${ }^{\circ} \mathrm{C}$; TLC: $\mathrm{R}_{\mathrm{f}}=0.18$ (ethyl acetate-DCM-hexane 3:1:3 v/v); IR (ATR) v / $\mathrm{cm}^{-1} 3031,2917,2364,2022,1976$, 1640, 1599, 1246; ${ }^{1} \mathrm{H}$ NMR (300 MHz, $\left.\mathrm{CDCl}_{3}\right) \delta 2.35$ (s, $6 \mathrm{H}), 5.24(\mathrm{~s}, 4 \mathrm{H}), 5.49(\mathrm{~s}, 4 \mathrm{H}), 7.02(\mathrm{~d}, 4 \mathrm{H}, J 8.1 \mathrm{~Hz})$, $7.20(\mathrm{~s}, 4 \mathrm{H}), 7.53(\mathrm{~s}, 2 \mathrm{H}), 7.75(\mathrm{~d}, 4 \mathrm{H}, J 8.1 \mathrm{~Hz}),{ }^{13} \mathrm{C} \mathrm{NMR}$ $\left(75 \mathrm{MHz}, \mathrm{CDCl}_{3}\right) \delta 21.2,54.1,62.1,114.2,122.7,128.2$, 129.8, 131.0, 131.3, 132.2, 138.9, 143.8, 161.4, 194.3; HRMS $m / z$, calculated for $\mathrm{C}_{35} \mathrm{H}_{33} \mathrm{~N}_{6} \mathrm{O}_{3}[\mathrm{M}+\mathrm{H}]^{+}:$585.2609, found: 585.2604 .
Bis(4-(1-(3-nitrobenzyl)-1H-1,2,3-triazol-4-yl)methoxy) benzophenone (12)

Yield: $54 \%$ (0.181 g, $0.280 \mathrm{mmol})$; white solid; $\mathrm{mp}$ 171-172 ${ }^{\circ} \mathrm{C}$; TLC: $\mathrm{R}_{\mathrm{f}}=0.10$ (ethyl acetate-DCM-hexane $3: 1: 3 \mathrm{v} / \mathrm{v}) ;$ IR (ATR) $\mathrm{v} / \mathrm{cm}^{-1} 3101,2351,1976,1642,1599$, 1528,$1246 ;{ }^{1} \mathrm{H}$ NMR $\left(300 \mathrm{MHz}, \mathrm{CDCl}_{3}\right) \delta 5.30(\mathrm{~s}, 4 \mathrm{H})$, $5.66(\mathrm{~s}, 4 \mathrm{H}), 7.03(\mathrm{~d}, 4 \mathrm{H}, J 8.7 \mathrm{~Hz}), 7.56-7.61(\mathrm{~m}, 4 \mathrm{H}), 7.67$ (s, 2H), $7.76(\mathrm{~d}, 4 \mathrm{H}, J 8.7 \mathrm{~Hz}), 8.17(\mathrm{~s}, 2 \mathrm{H}), 8.24(\mathrm{~d}, 4 \mathrm{H}$, $J 7.2 \mathrm{~Hz}) ;{ }^{13} \mathrm{C}$ NMR $\left(75 \mathrm{MHz}, \mathrm{CDCl}_{3}\right) \delta 53.3,62.0,114.3$, 122.9, 123.9, 130.4, 131.2, 132.2, 133.9, 136.4, 144.5, 148.6, 161.4, 194.3; HRMS m/z, calculated for $\mathrm{C}_{33} \mathrm{H}_{27} \mathrm{~N}_{8} \mathrm{O}_{7}$ $[\mathrm{M}+\mathrm{H}]^{+}:$647.1997, found: 647.1995 .

Bis(4-(1-(2,4-difluorobenzyl)-1H-1,2,3-triazol-4-yl)methoxy) benzophenone (13)

Yield: $57 \%$ (0.185 g, $0.294 \mathrm{mmol})$; white solid; $\mathrm{mp}$ 180-181 ${ }^{\circ} \mathrm{C}$; TLC: $\mathrm{R}_{\mathrm{f}}=0.10$ (ethyl acetate-DCM-hexane $3: 1: 3 \mathrm{v} / \mathrm{v}) ;$ IR (ATR) $\mathrm{v} / \mathrm{cm}^{-1} 3140,2886,2009,1978,1638$, 1600, 1259; ${ }^{1} \mathrm{H}$ NMR (300 MHz, $\left.\mathrm{CDCl}_{3}\right) \delta 5.26(\mathrm{~s}, 4 \mathrm{H})$, $5.56(\mathrm{~s}, 4 \mathrm{H}), 6.85-6.92(\mathrm{~m}, 4 \mathrm{H}), 7.03(\mathrm{~d}, 4 \mathrm{H}, J 8.7 \mathrm{~Hz})$, 7.26-7.36 (m, 2H), $7.70(\mathrm{~s}, 2 \mathrm{H}), 7.76(\mathrm{~d}, 4 \mathrm{H}, J 8.7 \mathrm{~Hz})$; ${ }^{13} \mathrm{C}$ NMR $\left(75 \mathrm{MHz}, \mathrm{CDCl}_{3}\right) \delta 47.3(\mathrm{~d}, J 3.8 \mathrm{~Hz}), 62.0$, 104.5 (t, $J 25.2 \mathrm{~Hz}), 112.2(\mathrm{dd}, J 21.5,3.8 \mathrm{~Hz}), 114.2$, 117.8 (dd, $J$ 14.9, $3.8 \mathrm{~Hz}), 122.8,131.1,131.8$ (dd, $J$ 9.9, $4.8 \mathrm{~Hz}), 132.2,144.0,161.4,162.1$ (dd, $J 52.1,12.0 \mathrm{~Hz}$ ), 194.3; HRMS $m / z$, calculated for $\mathrm{C}_{33} \mathrm{H}_{25} \mathrm{~F}_{4} \mathrm{~N}_{6} \mathrm{O}_{3}[\mathrm{M}+\mathrm{H}]^{+}$: 629.1919, found: 629.1911.

Bis(4-(1-(2-chlorobenzyl)-1H-1,2,3-triazol-4-yl)methoxy) benzophenone (14)

Yield: $60 \%$ (0.193 g, $0.310 \mathrm{mmol})$; white solid; mp 176-177 ${ }^{\circ} \mathrm{C}$; TLC: $\mathrm{R}_{\mathrm{f}}=0.21$ (ethyl acetate-DCM-hexane 3:1:3 v/v); IR (ATR) v / $\mathrm{cm}^{-1} 3098,2943,1970,1640,1599$, 1257; ${ }^{1} \mathrm{H} \mathrm{NMR}\left(300 \mathrm{MHz}, \mathrm{CDCl}_{3}\right) \delta 5.27$ (s, 4H), 5.68 (s, $4 \mathrm{H}), 7.03(\mathrm{~d}, 4 \mathrm{H}, J 8.7 \mathrm{~Hz}), 7.21-7.34(\mathrm{~m}, 6 \mathrm{H}), 7.43(\mathrm{~d}, 2 \mathrm{H}$, $J 8.7 \mathrm{~Hz}), 7.67(\mathrm{~s}, 2 \mathrm{H}), 7.75(\mathrm{~d}, 4 \mathrm{H}, J 8.7 \mathrm{~Hz}) ;{ }^{13} \mathrm{C} \mathrm{NMR}$ $\left(75 \mathrm{MHz}, \mathrm{CDCl}_{3}\right) \delta 51.5,62.0,114.3,123.1,127.6,129.9$, 130.4, 130.5, 131.1, 132.2, 132.2, 133.5, 143.8, 161.4, 194.3; HRMS $m / z$, calculated for $\mathrm{C}_{33} \mathrm{H}_{27} \mathrm{Cl}_{2} \mathrm{~N}_{6} \mathrm{O}_{3}[\mathrm{M}+\mathrm{H}]^{+}$: 625.1516, found: 625.1505 .

Bis(4-(1-(2,6-dichlorobenzyl)-1H-1,2,3-triazol-4-yl)methoxy) benzophenone (15)

Yield: $57 \%$ (0.204 g, $0.294 \mathrm{mmol}$ ); white solid; mp 187-188 ${ }^{\circ} \mathrm{C}$; TLC: $\mathrm{R}_{\mathrm{f}}=0.33$ (ethyl acetate-DCM-hexane 3:1:3 v/v); IR (ATR) $\mathrm{v} / \mathrm{cm}^{-1} 3094,2354,1976,1642,1600$, 1256; ${ }^{1} \mathrm{H}$ NMR (300 MHz, $\left.\mathrm{CDCl}_{3}\right) \delta 5.24(\mathrm{~s}, 4 \mathrm{H}), 5.87$ (s, $4 \mathrm{H}), 7.03(\mathrm{~d}, 4 \mathrm{H}, J 8.7 \mathrm{~Hz}), 7.25-7.33(\mathrm{~m}, 2 \mathrm{H}), 7.41(\mathrm{~d}$, $J 8.1 \mathrm{~Hz}), 7.62(\mathrm{~s}, 2 \mathrm{H}), 7.75(\mathrm{~d}, 4 \mathrm{H}, J 8.7 \mathrm{~Hz}) ;{ }^{13} \mathrm{C} \mathrm{NMR}$ $\left(75 \mathrm{MHz}, \mathrm{CDCl}_{3}\right) \delta 49.1,62.1,114.3,122.7,128.9,129.9$, 131.1, 131.2, 132.2, 136.8, 143.4, 161.4, 194.3; HRMS 
$m / z$, calculated for $\mathrm{C}_{33} \mathrm{H}_{24} \mathrm{Cl}_{4} \mathrm{~N}_{6} \mathrm{NaO}_{3}[\mathrm{M}+\mathrm{H}]^{+}:$717.3833, found: 717.0584 .

Bis(4-(1-(2-bromobenzyl)-1H-1,2,3-triazol-4-yl)methoxy) benzophenone (16)

Yield: $51 \%$ (0.295 g, $0.413 \mathrm{mmol})$; white solid; mp 166-167 ${ }^{\circ} \mathrm{C}$; TLC: $\mathrm{R}_{\mathrm{f}}=0.24$ (ethyl acetate-DCM-hexane $3: 1: 3 \mathrm{v} / \mathrm{v}$ ); IR (ATR) v / $\mathrm{cm}^{-1} 3096,2366,1976,1640,1596$, 1232; ${ }^{1} \mathrm{H}$ NMR (300 MHz, $\left.\mathrm{CDCl}_{3}\right) \delta 5.28(\mathrm{~s}, 4 \mathrm{H}), 5.68(\mathrm{~s}$, $4 \mathrm{H}), 7.03(\mathrm{~d}, 4 \mathrm{H}, J 8.1 \mathrm{~Hz}), 7.20-7.29(\mathrm{~m}, 6 \mathrm{H}), 7.33(\mathrm{~d}, 2 \mathrm{H}$, $J 7.8 \mathrm{~Hz}), 7.64(\mathrm{~d}, 4 \mathrm{H}, J 8.1 \mathrm{~Hz}), 7.68(\mathrm{~s}, 2 \mathrm{H}) ;{ }^{13} \mathrm{C} \mathrm{NMR}$ $\left(75 \mathrm{MHz}, \mathrm{CDCl}_{3}\right) \delta 53.9,62.1,114.3,123.1,123.5$, $128.3,130.4,130.5,131.1,132.2,133.3,133.9,143.8$, 161.4, 194.3; HRMS $m / z$, calculated for $\mathrm{C}_{33} \mathrm{H}_{26} \mathrm{Br}_{2} \mathrm{~N}_{6} \mathrm{NaO}_{3}$ $[\mathrm{M}+\mathrm{H}]^{+}:$737.3952, found: 737.0310 .

Bis(4-((1-(4-trifluoromethoxy)benzyl)-1H-1,2,3-triazol-4-yl) methoxy)benzophenone (17)

Yield: $58 \%$ (0.100 g, $0.139 \mathrm{mmol})$; white solid; $\mathrm{mp}$ 178-179 ${ }^{\circ} \mathrm{C}$; TLC: $\mathrm{R}_{\mathrm{f}}=0.11$ (ethyl acetate-DCM-hexane $3: 1: 3 \mathrm{v} / \mathrm{v}) ;$ IR (ATR) $\mathrm{v} / \mathrm{cm}^{-1} 3131,2186,1976,1640,1600$, $1251 ;{ }^{1} \mathrm{H}$ NMR $\left(300 \mathrm{MHz}, \mathrm{CDCl}_{3}\right) \delta 5.27$ (s, 4H), 5.61 (s, 4H), $7.02(\mathrm{~d}, J 8.7 \mathrm{~Hz}), 7.38(\mathrm{~d}, 4 \mathrm{H}, J 8.4 \mathrm{~Hz}), 7.63(\mathrm{~d}$, $6 \mathrm{H}, J 9.6 \mathrm{~Hz}), 7.75$ (d, 4H, $J 8.4 \mathrm{~Hz}) ;{ }^{13} \mathrm{C}$ NMR $(75 \mathrm{MHz}$, $\left.\mathrm{CDCl}_{3}\right) \delta 53.6,62.0,114.2,122.9,123.7$ (q, $J 270.8 \mathrm{~Hz}$ ), 126.2 (q, $J 7.5 \mathrm{~Hz}), 128.3,131.1$ (q, $J 18.6 \mathrm{~Hz}), 132.2$, 138.3, 144.3, 161.3, 194.3; HRMS $\mathrm{m} / \mathrm{z}$, calculated for $\mathrm{C}_{35} \mathrm{H}_{27} \mathrm{~F}_{6} \mathrm{~N}_{6} \mathrm{O}_{5}[\mathrm{M}+\mathrm{H}]^{+}:$: 725.1942, found: 725.1936 .

Bis(4-((1-(4-trifluoromethyl)benzyl)-1H-1,2,3-triazol-4-yl) methoxy)benzophenone (18)

Yield: 58\% (0.209 g, $0.302 \mathrm{mmol})$; white solid; mp 161-162 ${ }^{\circ} \mathrm{C}$; TLC: $\mathrm{R}_{\mathrm{f}}=0.13$ (ethyl acetate-DCM-hexane $3: 1: 3 \mathrm{v} / \mathrm{v}$ ); IR (ATR) $\mathrm{v} / \mathrm{cm}^{-1} 3109,2608,1605,1598,1246$; ${ }^{1} \mathrm{H}$ NMR $\left(300 \mathrm{MHz}, \mathrm{CDCl}_{3}\right) \delta 5.27(\mathrm{~s}, 4 \mathrm{H}), 5.53(\mathrm{~s}, 4 \mathrm{H})$, $7.03(\mathrm{~d}, 4 \mathrm{H}, J 7.8 \mathrm{~Hz}), 7.23$ (d, 4H, J 8.3 Hz), $7.32(\mathrm{~d}, 4 \mathrm{H}$, $J 8.3 \mathrm{~Hz}), 7.60(\mathrm{~s}, 2 \mathrm{H}), 7.76(\mathrm{~d}, 4 \mathrm{H}, J 7.8 \mathrm{~Hz}) ;{ }^{13} \mathrm{C} \mathrm{NMR}$ $\left(75 \mathrm{MHz}, \mathrm{CDCl}_{3}\right) \delta 53.4,62.0,114.2,120.3$ (q, $J 256.5 \mathrm{~Hz}$ ), 121.6, 122.8, 129.6, 131.1, 132.2, 133.0, 144.2, 149.5, 161.4, 194.3; HRMS $m / z$, calculated for $\mathrm{C}_{35} \mathrm{H}_{27} \mathrm{~F}_{6} \mathrm{~N}_{6} \mathrm{O}_{3}$ : $693.2043[\mathrm{M}+\mathrm{H}]^{+}$, found: 693.2024 .

\section{Synthesis of target compounds 19-29}

A round bottom flask $(50 \mathrm{~mL})$ was charged with 2-hydroxy-4-(prop-2-yn-1-yloxy)benzophenone (2b) (1.00 equiv.), benzyl azide (1.20 equiv.), sodium ascorbate ( 0.400 equiv.), dichloromethane $(1.50 \mathrm{~mL})$, distilled water $(1.50 \mathrm{~mL})$, and $\mathrm{CuSO}_{4} \cdot 5 \mathrm{H}_{2} \mathrm{O}(0.200$ equiv.). The resulting reaction mixture was vigorously stirred at room temperature for $1 \mathrm{~h}$ and the progress of the reaction was monitored by
TLC analysis. The reaction was quenched by addition of saturated sodium bicarbonate aqueous solution $(15 \mathrm{~mL})$. The layers were separated, and the aqueous phase was extracted with dichloromethane $(3 \times 20 \mathrm{~mL})$. The organic extracts were combined, and the resulting organic layer was dried over anhydrous sodium sulfate, filtered, and concentrated under reduced pressure to provide crude compounds. Compounds 19-29 were purified by silica gel flash column chromatography eluted with hexane-ethyl acetate $2: 1 \mathrm{v} / \mathrm{v}$. Structures of the synthesized compounds are supported by the following data.

2-Hydroxy-(4-((1-benzyl)-1H-1,2,3-triazol-4-yl)methoxy) benzophenone (19)

Yield: $78 \%$ (0.172 g, $0.446 \mathrm{mmol})$; white solid; mp 98-99 ${ }^{\circ} \mathrm{C}$; TLC: $\mathrm{R}_{\mathrm{f}}=0.33$ (hexane-ethyl acetate $2: 1 \mathrm{v} / \mathrm{v}$ ); IR (ATR) v / $\mathrm{cm}^{-1} 3137,2923,2856,2364,2159,2021$, 1618, 1596, 1573, 1497, 1340, 1252, 1161, 1111, 1049, 1001, 978, 805, 679, 619; ${ }^{\mathrm{H}} \mathrm{HMR}\left(300 \mathrm{MHz}, \mathrm{CDCl}_{3}\right)$ $\delta 5.21(\mathrm{~s}, 2 \mathrm{H}), 5.54(\mathrm{~s}, 2 \mathrm{H}), 6.46(\mathrm{dd}, 1 \mathrm{H}, J 2.1,8.9 \mathrm{~Hz})$, $6.59(\mathrm{~s}, 1 \mathrm{H}), 7.28(\mathrm{dd}, 1 \mathrm{H}, J 2.2,6.8 \mathrm{~Hz}), 7.36-7.38(\mathrm{~m}$, $3 \mathrm{H}), 7.45-7.53(\mathrm{~m}, 4 \mathrm{H}), 7.57(\mathrm{~s}, 1 \mathrm{H}), 7.61(\mathrm{~d}, 2 \mathrm{H}, J 6.9 \mathrm{~Hz})$, $12.64(\mathrm{~s}, 1 \mathrm{H}) ;{ }^{13} \mathrm{C} \mathrm{NMR}\left(75 \mathrm{MHz}, \mathrm{CDCl}_{3}\right) \delta 54.2,62.0$, 102.0, 107.4, 113.4, 122.8, 122.9, 128.1, 128.3, 129.1, 131.5, 134.2, 135.3, 135.4, 138.0, 164.5, 166.0, 200.0; HRMS $m / z$, calculated for $\mathrm{C}_{23} \mathrm{H}_{20} \mathrm{~N}_{3} \mathrm{O}_{3}[\mathrm{M}+\mathrm{H}]^{+}: 386.1499$, found: 386.1497 .

2-Hydroxy-(4-((1-(3-methyl)benzyl)-1H-1,2,3-triazol-4-yl) methoxy)benzophenone (20)

Yield: $89 \%$ (0.212 g, $0.531 \mathrm{mmol})$; white solid; $\mathrm{mp}$ 77-78 ${ }^{\circ} \mathrm{C}$; TLC: $\mathrm{R}_{\mathrm{f}}=0.47$ (hexane-ethyl acetate $2: 1 \mathrm{v} / \mathrm{v}$ ); IR (ATR) v / $\mathrm{cm}^{-1} 3138,3058,2923,2366,1618,1574$, 1501, 1445, 1341, 1254, 1189, 1162, 1113, 1003, 910, 699; $\left.{ }^{1} \mathrm{H} \mathrm{NMR} \mathrm{(300} \mathrm{MHz,} \mathrm{CDCl}_{3}\right) \delta 2.34(\mathrm{~s}, 3 \mathrm{H}), 5.22$ (s, $2 \mathrm{H}), 5.50(\mathrm{~s}, 2 \mathrm{H}), 6.46(\mathrm{dd}, 1 \mathrm{H}, J 2.1,9.0 \mathrm{~Hz}), 6.59(\mathrm{~s}$, $1 \mathrm{H}), 7.08(\mathrm{~d}, 2 \mathrm{H}, J 6.6 \mathrm{~Hz}), 7.17(\mathrm{~d}, 1 \mathrm{H}, J 7.5 \mathrm{~Hz}), 7.26(\mathrm{t}$, 1H, 7.5 Hz), 7.46-7.54 (m, 4H), $12.63(\mathrm{~s}, 1 \mathrm{H}) ;{ }^{13} \mathrm{C} \mathrm{NMR}$ $\left(75 \mathrm{MHz}, \mathrm{CDCl}_{3}\right) \delta 21.1,54.3,62.1,102.1,107.5,113.5$, $122.8,122.9,125.2,128.3,128.9,129.0,129.6,131.5$, 134.2, 135.4, 138.1, 139.1, 143.4, 164.6, 166.1, 200.1; HRMS $m / z$, calculated for $\mathrm{C}_{24} \mathrm{H}_{22} \mathrm{~N}_{3} \mathrm{O}_{3}[\mathrm{M}+\mathrm{H}]^{+}: 400.1656$, found: 400.1657 .

2-Hydroxy-(4-((1-(4-chloro)benzyl)-1H-1,2,3-triazol-4-yl) methoxy)benzophenone (21)

Yield: $71 \%$ (0.177 g, $0.422 \mathrm{mmol})$; white solid; mp 87-88 ${ }^{\circ} \mathrm{C}$; TLC: $\mathrm{R}_{\mathrm{f}}=0.30$ (hexane-ethyl acetate $2: 1 \mathrm{v} / \mathrm{v}$ ); IR (ATR) $v / \mathrm{cm}^{-1} 3138,3058,3028,2923,2366,1618$, 1574, 1501, 1406, 1445, 1341, 1253, 1225, 1161, 1188, 1111, 1049, 1002, 978, 909, 801, 734, 698, 615; ${ }^{1} \mathrm{H}$ NMR 
(300 MHz, $\left.\mathrm{CDCl}_{3}\right) \delta 5.22(\mathrm{~s}, 2 \mathrm{H}), 5.51(\mathrm{~s}, 2 \mathrm{H}), 6.46(\mathrm{dd}$, $1 \mathrm{H}, J 2.1,9.0 \mathrm{~Hz}), 6.59(\mathrm{~s}, 1 \mathrm{H}), 7.15(\mathrm{~d}, 2 \mathrm{H}, J 8.1 \mathrm{~Hz})$, $7.35(\mathrm{~d}, 2 \mathrm{H}, J 8.1 \mathrm{~Hz}), 7.46-7.54(\mathrm{~m}, 4 \mathrm{H}), 7.57(\mathrm{~s}, 1 \mathrm{H})$, $7.61(\mathrm{~d}, 2 \mathrm{H}, J 7.8 \mathrm{~Hz}), 12.64(\mathrm{~s}, 1 \mathrm{H}) ;{ }^{13} \mathrm{C}$ NMR $(75 \mathrm{MHz}$, $\left.\mathrm{CDCl}_{3}\right) \delta 53.6,62.1,102.1,107.4,113.6,122.8,122.9$, $128.3,128.8,129.4,129.5,131.6,132.8,134.9,138.1$, 143.6, 164.5, 166.0, 200.1; HRMS $\mathrm{m} / \mathrm{z}$, calculated for $\mathrm{C}_{23} \mathrm{H}_{20} \mathrm{ClN}_{3} \mathrm{O}_{3}[\mathrm{M}+\mathrm{H}]^{+}:$420.1109, found: 420.1109 .

2-Hydroxy-(4-((1-(3-nitro)benzyl)-1H-1,2,3-triazol-4-yl) methoxy)benzophenone (22)

Yield: $73 \%$ (0.186 g, $0.422 \mathrm{mmol}$ ); white solid; mp 127-128 ${ }^{\circ} \mathrm{C}$; TLC: $\mathrm{R}_{\mathrm{f}}=0.24$ (hexane-ethyl acetate 2:1 v/v); IR (ATR) v / $\mathrm{cm}^{-1} 3143,3058,2966,2933,1700$, 1619, 1597, 1574, 1492, 1341, 1253, 1225, 1188, 1161, $1111,1002,909,801,734,698,615 ;{ }^{1} \mathrm{H}$ NMR $(300 \mathrm{MHz}$, $\left.\mathrm{CDCl}_{3}\right) \delta 5.25(\mathrm{~s}, 2 \mathrm{H}), 5.66(\mathrm{~s}, 2 \mathrm{H}), 6.46(\mathrm{dd}, 1 \mathrm{H}, J 2.1$, $9.0 \mathrm{~Hz}), 6.58(\mathrm{~s}, 1 \mathrm{H}), 7.45-7.62(\mathrm{~m}, 8 \mathrm{H}), 7.69(\mathrm{~s}, 1 \mathrm{H}), 8.16$ $(\mathrm{s}, 1 \mathrm{H}), 8.21(\mathrm{~d}, 1 \mathrm{H}, J 7.5 \mathrm{~Hz}), 12.62(\mathrm{~s}, 1 \mathrm{H}) ;{ }^{13} \mathrm{C} \mathrm{NMR}$ $\left(75 \mathrm{MHz}, \mathrm{CDCl}_{3}\right) \delta$ 53.2, 62.0, 102.1, 107.4, 113.9, 123.0, $123.1,123.9,128.3,128.8,130.4,131.6,133.7,135.5$, 136.4, 138.0, 143.9, 148.5, 164.5, 166.0, 200.1; HRMS $m / z$, calculated for $\mathrm{C}_{23} \mathrm{H}_{19} \mathrm{~N}_{4} \mathrm{O}_{5}[\mathrm{M}+\mathrm{H}]^{+}: 431.1349$, found: 431.1353 .

2-Hydroxy-(4-((1-(4-bromo)benzyl)-1H-1,2,3-triazol-4-yl) methoxy)benzophenone (23)

Yield: $95 \%$ (0.261 g, $0.562 \mathrm{mmol})$; white solid; mp 121-122 ${ }^{\circ} \mathrm{C}$; TLC: $\mathrm{R}_{\mathrm{f}}=0.41$ (hexane-ethyl acetate $2: 1$ $\mathrm{v} / \mathrm{v}$ ); IR (ATR) $\mathrm{v} / \mathrm{cm}^{-1} 3143,3058,2929,1700,1618,1597$, 1574, 1558, 1502, 1445, 1344, 1253, 1225, 1189, 1169, $1112,1003,909,732 ;{ }^{1} \mathrm{H}$ NMR (300 MHz, $\left.\mathrm{CDCl}_{3}\right) \delta 5.22$ (s, 2H), 5.49 (s, 2H), 6.46 (dd, 1H, J 2.3, 8.7 Hz), 6.59 (s, $1 \mathrm{H}), 7.15(\mathrm{~d}, 2 \mathrm{H}), 7.46-7.63(\mathrm{~m}, 9 \mathrm{H}), 12.64(\mathrm{~s}, 1 \mathrm{H}) ;{ }^{13} \mathrm{C} \mathrm{NMR}$ $\left(75 \mathrm{MHz}, \mathrm{CDCl}_{3}\right) \delta 53.6,62.1,102.1,107.4,113.6,122.8$, $122.9,123.1,128.3,128.8,129.7,131.6,132.4,133.3$, 138.1, 143.6, 164.6, 166.1, 200.1; HRMS $\mathrm{m} / \mathrm{z}$, calculated for $\mathrm{C}_{23} \mathrm{H}_{19} \mathrm{BrN}_{3} \mathrm{O}_{3}[\mathrm{M}+\mathrm{H}]^{+}$: 464.0604, found: 464.0601 .

2-Hydroxy-(4-((1-(2,4-difluoro)benzyl)-1H-1,2,3-triazol-4-yl) methoxy)benzophenone (24)

Yield: $46 \%$ (0.116 g, $0.401 \mathrm{mmol})$; white solid; mp 108-109 ${ }^{\circ} \mathrm{C}$; TLC: $\mathrm{R}_{\mathrm{f}}=0.32$ (hexane-ethyl acetate 2:1 $\mathrm{v} / \mathrm{v})$; IR (ATR) $\mathrm{v} / \mathrm{cm}^{-1} 3151,3099,2923,1621,1595$, 1573, 1505, 1445, 1429, 1349, 1342, 1281, 1260, 1184, 1159, 1121, 1095, 1047, 1004, 979, 936, 910, 846, 788, 696, 654, 629; ${ }^{1} \mathrm{H}$ NMR (300 MHz, $\left.\mathrm{CDCl}_{3}\right) \delta 5.22(\mathrm{~s}$, $2 \mathrm{H}), 5.56(\mathrm{~s}, 2 \mathrm{H}), 6.47(\mathrm{dd}, 1 \mathrm{H}, J 2.0,9.0 \mathrm{~Hz}), 6.60(\mathrm{~s}$, $1 \mathrm{H}), 6.88-6.92(\mathrm{~m}, 2 \mathrm{H}), 7.26-7.36(\mathrm{~m}, 1 \mathrm{H}), 7.46-7.56(\mathrm{~m}$, 4H), $7.62(\mathrm{~d}, 2 \mathrm{H}, J 6.9 \mathrm{~Hz}), 7.67(\mathrm{~s}, 1 \mathrm{H}), 12.63(\mathrm{~s}, 1 \mathrm{H})$; ${ }^{13} \mathrm{C}$ NMR $\left(75 \mathrm{MHz}, \mathrm{CDCl}_{3}\right) \delta 47.3,62.1,102.2,104.4$ (q,
$J 25.6 \mathrm{~Hz}), 107.4,112.3,113.5,123.0,128.3,128.8,131.6$, 131.7 (q, $J 5.0 \mathrm{~Hz}), 135.4,138.1,143.5,164.6,166.1$, 200.1; HRMS $m / z$, calculated for $\mathrm{C}_{23} \mathrm{H}_{18} \mathrm{~F}_{2} \mathrm{~N}_{3} \mathrm{O}_{3}[\mathrm{M}+\mathrm{H}]^{+}$: 422.1310, found: 422.1309 .

2-Hydroxy-(4-((1-(4-trifluoromethyl)benzyl)-1H-1,2,3-triazol4-yl)methoxy)benzophenone (25)

Yield: $94 \%$ (0.253 g, $0.558 \mathrm{mmol})$; white solid; mp $132-133{ }^{\circ} \mathrm{C}$; TLC: $\mathrm{R}_{\mathrm{f}}=0.28$ (hexane-ethyl acetate $2: 1$ $\mathrm{v} / \mathrm{v})$; IR (ATR) v / $\mathrm{cm}^{-1} 3137,3087,2926,2366,2016$, 1618, 1597, 1573, 1503, 1445, 1419, 1322, 1252, 1159, 1111, 1065, 1017, 920, 808, 701; 'H NMR (300 MHz, $\left.\mathrm{CDCl}_{3}\right) \delta 5.23(\mathrm{~s}, 2 \mathrm{H}), 5.61(\mathrm{~s}, 2 \mathrm{H}), 6.47(\mathrm{~d}, 1 \mathrm{H}, J 8.7 \mathrm{~Hz})$, $6.59(\mathrm{~s}, 1 \mathrm{H}), 7.38(\mathrm{~d}, 2 \mathrm{H}, J 8.1 \mathrm{~Hz}), 7.45-7.56(\mathrm{~m}, 4 \mathrm{H})$, 7.60-7.62 (m, 4H), $7.65(\mathrm{~s} 1 \mathrm{H}), 12.61(\mathrm{~s}, 1 \mathrm{H}) ;{ }^{13} \mathrm{C} \mathrm{NMR}$ $\left(75 \mathrm{MHz}, \mathrm{CDCl}_{3}\right) \delta 53.6,62.1,102.2,107.4,113.6,122.9$, 126.1 (q, J 3.6, 7.5 Hz), 128.2, 128.3, 128.8, 131.5, 135.4, 138.1, 143.8, 164.5, 166.1, 200.1; HRMS $\mathrm{m} / \mathrm{z}$, calculated for $\mathrm{C}_{24} \mathrm{H}_{19} \mathrm{~F}_{3} \mathrm{~N}_{3} \mathrm{O}_{3}[\mathrm{M}+\mathrm{H}]^{+}$: 454.1373, found: 454.1374 .

2-Hydroxy-(4-((1-(4-trifluoromethoxy)benzyl)-1H-1,2,3-triazol4-yl)methoxy)benzophenone (26)

Yield: $93 \%$ (0.261 g, $0.556 \mathrm{mmol})$; white solid; mp 97-98 ${ }^{\circ} \mathrm{C}$; TLC: $\mathrm{R}_{\mathrm{f}}=0.28$ (hexane-ethyl acetate $2: 1$ $\mathrm{v} / \mathrm{v})$; IR (ATR) $\mathrm{v} / \mathrm{cm}^{-1} 3135,2923,2852,2364,2163$, 1702, 1619, 1597, 1508, 1445, 1342, 1250, 1217, 1157, $1111,1002,918,808,699,598 ;{ }^{1} \mathrm{H}$ NMR $(300 \mathrm{MHz}$, $\left.\mathrm{CDCl}_{3}\right) \delta 5.22(\mathrm{~s}, 2 \mathrm{H}), 5.54(\mathrm{~s}, 2 \mathrm{H}), 6.45(\mathrm{dd}, 1 \mathrm{H}, J 1.8$, $9.0 \mathrm{~Hz}), 6.59$ (s, 1H), $7.21(\mathrm{~d}, 2 \mathrm{H}, J 8.3 \mathrm{~Hz}), 7.31(\mathrm{~d}, 2 \mathrm{H}$, $J 8.3 \mathrm{~Hz}), 7.44-7.55(\mathrm{~m}, 4 \mathrm{H}), 7.59$ (s, 2H), $7.62(\mathrm{~s}, 1 \mathrm{H})$, $12.60(\mathrm{~s}, 1 \mathrm{H}) ;{ }^{13} \mathrm{C}$ NMR $\left(75 \mathrm{MHz}, \mathrm{CDCl}_{3}\right) \delta 53.4,62.1$, 102.2, 107.4, 113.6, 120.4 (q, $J 249.5 \mathrm{~Hz}), 121.5,122.8$, $128.3,128.8,129.6,131.5,133.1,135.4,149.5,164.4$, 166.1, 200.0; HRMS $m / z$, calculated for $\mathrm{C}_{24} \mathrm{H}_{19} \mathrm{~F}_{3} \mathrm{~N}_{3} \mathrm{O}_{4}$ $[\mathrm{M}+\mathrm{H}]^{+}:$470.1322, found: 470.1318 .

2-Hydroxy-(4-((1-(4-iodo)benzyl)-1H-1,2,3-triazol-4-yl) methoxy)benzophenone (27)

Yield: $78 \%$ (0.231 g, $0.452 \mathrm{mmol})$; white solid; $\mathrm{mp}$ 144- $145^{\circ} \mathrm{C}$; TLC: $\mathrm{R}_{\mathrm{f}}=0.28$ (hexane-ethyl acetate $2: 1 \mathrm{v} / \mathrm{v}$ ); IR (ATR) $v / \mathrm{cm}^{-1} 3141,3060,2922,2853,2360,1734$, $1618,1595,1574,1501,1486,1445,1402,1341,1252$, 1188, 1112, 977, 935, 796, 757, 699, 619, 598, 532, 472; ${ }^{1} \mathrm{H}$ NMR $\left(300 \mathrm{MHz}, \mathrm{CDCl}_{3}\right) \delta 5.20(\mathrm{~s}, 2 \mathrm{H}), 5.46(\mathrm{~s}, 2 \mathrm{H})$, $6.44(\mathrm{~d}, 1 \mathrm{H}, J 9.0 \mathrm{~Hz}), 6.59(\mathrm{~s}, 1 \mathrm{H}), 7.00(\mathrm{~d}, 2 \mathrm{H}, J 8.3 \mathrm{~Hz})$, 7.43-7.54 (m, 4H), 7.59 (d, $3 \mathrm{H}, J 8.3 \mathrm{~Hz}), 7.68(\mathrm{~d}, 2 \mathrm{H}$, $J 8.4 \mathrm{~Hz}), 12.61(\mathrm{~s}, 1 \mathrm{H}) ;{ }^{13} \mathrm{C} \mathrm{NMR}\left(75 \mathrm{MHz}, \mathrm{CDCl}_{3}\right) \delta 53.7$, 62.0, 94.7, 102.1, 107.4, 113.5, 122.9, 128.3, 128.8, 129.9, 131.6, 134.0, 135.4, 138.1, 138.3, 143.6, 164.6, 166.1, 200.1; HRMS $m / z$, calculated for $\mathrm{C}_{23} \mathrm{H}_{19} \mathrm{IN}_{3} \mathrm{O}_{3}[\mathrm{M}+\mathrm{H}]^{+}$: 512.0465, found: 512.0452 . 
2-Hydroxy-(4-(1-(piridin-2-ylmethyl)-1H-1,2,3-triazol-4-yl) methoxy)benzophenone (28)

Yield: $68 \%$ (0.156 g, $0.404 \mathrm{mmol})$; white solid; mp 103-104 ${ }^{\circ} \mathrm{C}$; TLC: $\mathrm{R}_{\mathrm{f}}=0.45$ (hexane-ethyl acetate 2:1 $\mathrm{v} / \mathrm{v})$; IR (ATR) v / $\mathrm{cm}^{-1} 3141,3052,2924,2852,1752$, $1621,1549,1574,1500,1441,1345,1257,1223,1164$, $1113,1047,1051,997,976,935,910,838,751,697,617$, $596,535,466 ;{ }^{1} \mathrm{H} \mathrm{NMR}\left(300 \mathrm{MHz}, \mathrm{CDCl}_{3}\right) \delta 5.23(\mathrm{~s}, 2 \mathrm{H})$, $5.65(\mathrm{~s}, 2 \mathrm{H}), 6.46(\mathrm{dd}, 1 \mathrm{H}, J 1.5,9.0 \mathrm{~Hz}), 6.60(\mathrm{~s}, 1 \mathrm{H})$, $7.22(\mathrm{~d}, 1 \mathrm{H}, J 8.1 \mathrm{~Hz}), 7.27(\mathrm{~d}, 1 \mathrm{H}, J 7.5 \mathrm{~Hz}), 7.44-7.55$ $(\mathrm{m}, 4 \mathrm{H}), 7.61(\mathrm{~d}, 2 \mathrm{H}, J 7.0 \mathrm{~Hz}), 7.69(\mathrm{t}, 1 \mathrm{H}, J 7.7 \mathrm{~Hz}), 7.84$ (s, 1H), $8.58(\mathrm{br}, 1 \mathrm{H}), 12.62(\mathrm{~s}, 1 \mathrm{H}) ;{ }^{13} \mathrm{C}$ NMR $(75 \mathrm{MHz}$, $\left.\mathrm{CDCl}_{3}\right) \delta$ 55.7, 62.1, 102.1, 107.5, 113.5, 122.6, 123.5, $123.7,128.3,128.8,131.5,135.4,137.4,138.1,143.3$, 149.8, 154.1, 164.6, 166.1, 200.1; HRMS $\mathrm{m} / \mathrm{z}$, calculated for $\mathrm{C}_{23} \mathrm{H}_{19} \mathrm{IN}_{3} \mathrm{O}_{3}[\mathrm{M}+\mathrm{H}]^{+}:$387.1451, found: 387.1453 .

2-Hydroxy-(4-(1-(benzo[d][1,3]dioxol-5-ylmethyl)-1H-1,2,3triazol-4-yl)methoxy)benzophenone (29)

Yield: $35 \%$ (0.088 g, $0.228 \mathrm{mmol})$; white solid; mp 144- $145^{\circ} \mathrm{C}$; TLC: $\mathrm{R}_{\mathrm{f}}=0.38$ (hexane-ethyl acetate $2: 1$ $\mathrm{v} / \mathrm{v})$; IR (ATR) v / $\mathrm{cm}^{-1}$ 2922, 2852, 1620, 1597, 1575, 1502, 1491, 1445, 1342, 1248, 1189, 1162, 1113, 1035, 1003, 923, 801, 741, 699, 615, 598, 532, 465; ${ }^{1} \mathrm{H}$ NMR $\left(300 \mathrm{MHz}, \mathrm{CDCl}_{3}\right) \delta 5.21(\mathrm{~s}, 2 \mathrm{H}), 5.42(\mathrm{~s}, 2 \mathrm{H}), 5.96(\mathrm{~s}$, $2 \mathrm{H}), 6.46(\mathrm{dd}, 1 \mathrm{H}, J 2.4,9.0 \mathrm{~Hz}), 6.59(\mathrm{~s}, 1 \mathrm{H}), 6.75(\mathrm{~s}, 1 \mathrm{H})$, $6.79(\mathrm{~s}, 2 \mathrm{H}), 7.45-7.63(\mathrm{~m}, 4 \mathrm{H}), 7.55(\mathrm{~s}, 1 \mathrm{H}), 7.61(\mathrm{~d}, 2 \mathrm{H}$, $J 7.8 \mathrm{~Hz}), 12.63(\mathrm{~s}, 1 \mathrm{H}) ;{ }^{13} \mathrm{C} \mathrm{NMR}\left(75 \mathrm{MHz}, \mathrm{CDCl}_{3}\right) \delta 54.2$, 62.1, 101.5, 102.2, 107.4, 108.5, 108.6, 113.5, 122.1, 122.6, $127.8,128.3,128.8,131.5,135.4,138.1,143.4,148.2$, 148.3, 164.6, 166.1, 200.1; HRMS $\mathrm{m} / \mathrm{z}$, calculated for $\mathrm{C}_{24} \mathrm{H}_{20} \mathrm{~N}_{3} \mathrm{O}_{5}[\mathrm{M}+\mathrm{H}]^{+}:$430.1397, found: 430.1397 .

\section{Biological assays}

\section{In vitro sun protection factor}

Sun protection factor of each compound (2a, $\mathbf{2 b}$, 4-7, 10, 11, 13, 15, 17-28) was determined using the UV absorbance method in a microdilution plate reader (Thermo Scientific, Vantaa, Finland). Solutions of compounds were prepared at $0.2 \mu \mathrm{g} \mathrm{mL} \mathrm{m}^{-1}$ using ethanol as solvent. Ethanol was used as blank. Each experiment was performed in triplicate. Absorbance was observed in the range of 290-320 nm, with intervals of $5 \mathrm{~nm}$, according to Mansur's method. ${ }^{64}$ The SPF determination is the correlation between the erythemogenic effect (EE) and the radiation intensity (I) at each wavelength $(\lambda)$ (Table 4), adjusted according to equation 1 . The correction factor $(\mathrm{CF})$ is 10 and $\mathrm{Abs}(\lambda)$ is the sample spectrophotometric absorbance value at $\lambda$.

Spectrophotometric SPF $=\mathrm{CF} \times \sum_{290}^{320} \mathrm{EE}(\lambda) \times \mathrm{I}(\lambda) \times \operatorname{Abs}(\lambda)$
Table 4. Correlation between the erythemogenic effect (EE) and the radiation intensity (I) at each wavelength $(\lambda)^{64}$

\begin{tabular}{lc}
\hline$\lambda / \mathrm{nm}$ & $\mathrm{EE}(\lambda) \times \mathrm{I}(\lambda)$ \\
\hline 290 & 0.0150 \\
295 & 0.8170 \\
300 & 0.2874 \\
305 & 0.3278 \\
310 & 0.1864 \\
315 & 0.0839 \\
320 & 0.0180 \\
\hline
\end{tabular}

Determination of antioxidant activity (AC)

In vitro evaluations of the $\mathrm{AC}$ were performed through the DPPH method using the DPPH solution at $0.1 \mathrm{mmol} \mathrm{L}^{-1}$. The standard antioxidant used in all TEAC determinations was the synthetic antioxidant Trolox at concentrations ranging from 20 to $200 \mu \mathrm{mol} \mathrm{L} \mathrm{L}^{-1}$. At first, solutions at $2 \mathrm{mg} \mathrm{mL}^{-1}$ of $\mathbf{1 b}, \mathbf{2 a}, \mathbf{2 b}, \mathbf{5}, \mathbf{8}, \mathbf{1 3}, \mathbf{1 7 - 2 4}, \mathbf{2 6 - 2 8}$ were prepared using ethanol. From this solution, dilutions (1, $0.5,0.25,0.125$ and $0.062 \mathrm{mg} \mathrm{mL}^{-1}$ ) were made. The DPPH $(175 \mu \mathrm{L})$ was added to the sample $(25 \mu \mathrm{L})$ and absorbance was measured at $517 \mathrm{~nm}$ in a microdilution plate reader (Thermo Scientific, Vantaa, Finland) after 2 and $4 \mathrm{~h}$ of incubation at room temperature $\left(25 \pm 2{ }^{\circ} \mathrm{C}\right)$ in the dark. The TEAC was obtained by plotting the absorbance $(517 \mathrm{~nm})$ as a function of Trolox solution concentrations. The DPPH TEAC was expressed as $\mu \mathrm{mol}$ Trolox $\mathrm{mL}^{-1}$.

Cell lines and treatment schedule

Cell lines derived from human cancer were used in this study: A549 (lung carcinoma), MCF-7 (breast carcinoma), and HT-144 (metastatic melanoma). Fibroblast derived from normal skin (CCD-1059Sk) also was examined. The cell cultures were maintained in Dulbecco's modified Eagle's minimum essential medium (DMEM, Sigma-Aldrich, St. Louis, MO, USA) supplemented with $10 \%$ fetal bovine serum (Vitrocell, Campinas, Brazil). Cells were grown in a $37{ }^{\circ} \mathrm{C}$ humidified incubator containing $5 \% \mathrm{CO}_{2}$. Compounds were solubilized in DMSO to obtain a stock solution (20 $\mathrm{mmol} \mathrm{L}^{-1}$ ); subsequently, new dilutions were performed in culture medium immediately before the treatment. The final concentration of DMSO did not exceed $0.8 \%(\mathrm{v} / \mathrm{v})$.

Cell viability analysis

Cells were seeded into 96-wells plate at a density of $5 \times 10^{3}$ cells (A549 and CCD-1059Sk) or $1 \times 10^{4}$ cells 
(HT-144 and MCF-7). The cell cultures were treated with different compounds (2a, 2b, 4-29) at $40 \mu \mathrm{mol} \mathrm{L} \mathrm{L}^{-1}$ for $48 \mathrm{~h}$ to screen the most active substances. Cell viability was determined by MTS (3-(4.5-dimethylthiazol2-yl)-5-(3-carboxymethoxyphenyl)-2-(4-sulfophenyl)$2 \mathrm{H}$-tetrazolium) colorimetric assay using CellTiter $96^{\circledR}$ $\mathrm{AQ}_{\text {ueous }}$ Non-Radiactive Cell Proliferation Assay Kit (Promega Corporation, Madison, WI, USA) according to manufacturer's instructions. The MTS was added to the samples (10\% v/v in culture medium) and analysis was performed after $4 \mathrm{~h}$ in a spectrophotometric plate reader at $490 \mathrm{~nm}$. Relative viability was calculated according to equation 2. The experiments were conducted in triplicate wells and repeated twice. Data are presented as the mean \pm standard deviation (SD).

Cell viability $(\%)=($ Ab sample $\times 100) /($ Ab control $)(2)$

where $\mathrm{Ab}$ is the absorbance value.

Further, the $\mathrm{IC}_{50}$ values of the most promising substances were determined. Cell cultures were treated for $48 \mathrm{~h}$ with compounds at different concentrations (10, 20, 40, 80, and $160 \mu \mathrm{mol} \mathrm{L}{ }^{-1}$ ) and the $\mathrm{IC}_{50}$ values were determined from non-linear regression using GraphPad Prism. ${ }^{65}$ Cisplatin was used as a positive control at the same concentrations of the tested compounds.

\section{Cell cycle analysis}

Cell cycle progression analysis was performed according to Azevedo-Barbosa et al. ${ }^{66}$ Cells were seeded into $35 \mathrm{~mm}$ at $2 \times 10^{5}$ density. After adhesion $(24 \mathrm{~h})$ the cells were treated with the benzophenone-1,2,3-triazole derivatives for $48 \mathrm{~h}$ at $40 \mu \mathrm{mol} \mathrm{L}{ }^{-1}$. After that, the cells were collected by enzymatic digestion (trypsin-ethylenediamine tetraacetic acid (EDTA) solution (Sigma-Aldrich, St. Louis, MO, USA)) and fixed in ethanol at $4{ }^{\circ} \mathrm{C}(75 \%$ in PBS (phosphate buffered saline)) for $30 \mathrm{~min}$. The samples were incubated for $1 \mathrm{~h}$ with a solution containing PBS, RNAse (1.5 mg mL ${ }^{-1}$, Sigma-Aldrich, St. Louis, MO, USA) and propidium iodide $\left(90 \mu \mathrm{g} \mathrm{mL}^{-1}\right)$. The analysis was performed on a flow cytometer (Guava Mini EasyCyte, 8HT) using GuavaSoft 2.7 software ${ }^{67}$ The data presented refer to the mean $\pm \mathrm{SD}$ of three independent experiments performed in triplicate.

\section{Statistical analysis}

Data were expressed as the mean \pm SD. Analysis of variance (ANOVA) and Tukey's post-test was used to compare SPF and TEAC values to benzophenone-triazole derivatives. The $t$-test was used to compare TEAC values after two and four hours. ANOVA followed by Tukey's and Dunnett's post-test was used to cell viability. The software used was GraphPad Prism ${ }^{\circledR}$ 5.0. ${ }^{65}$

\section{Supplementary Information}

Supplementary information (IR, ${ }^{1} \mathrm{H}$ and ${ }^{13} \mathrm{C}$ NMR and HRMS spectra) is available free of charge at http://jbcs.sbq.org.br as PDF file.

\section{Acknowledgments}

This work was supported by FAPEMIG, CAPES, FINEP and CNPq. The authors would like to thank Professor Paulo C. Stringheta (Department of Food Technology, University Federal of Viçosa) for the acquisition of reagents to antioxidant test.

\section{Author Contributions}

Maria C. F. Dias was responsible for the synthesis, data curation, formal analysis, investigation, methodology, writing original draft, review and editing; Bianca L. de Sousa was responsible for the resources, review and editing; Marisa Ionta was responsible for the anticancer assays, data curation, formal analysis, investigation, methodology, writing original draft, review and editing; Róbson R. Teixeira was responsible for the resources, review and editing; Thiago Q. Goulart, was responsible for the synthesis, formal analysis, investigation, methodology; Guilherme A. Ferreira-Silva was responsible for the anticancer assays, formal analysis, investigation, methodology; Eduardo J. Pilau was responsible for the acquire the HRMS, methodology, formal analysis, review and editing; Marcelo H. Santos was responsible for the data curation, formal analysis, funding acquisition, investigation, methodology, project administration, resources, supervision, writing original draft, review and editing.

\section{References}

1. Surana, K.; Chaudhary, B.; Diwaker, M.; Sharma, S.; Med. Chem. Commun. 2018, 9, 1803.

2. Aranda, M. I. R.; Gómez, G. A. T.; de Barros, M.; dos Santos, M. H.; de Oliveira, L. L.; Pena, J. L.; Moreira, M. A. S.; Front. Microbiol. 2019, 10, 490.

3. Song, Z.; Wang, P.; Huang, S.; Wang, C.; Wang, R.-R.; Yang, L.-M.; Zhen, Y.; Liu, K.; Zheng, Y.-T.; Ma, X.; Med. Chem. 2016, 13, 398.

4. Skórkowska, A.; Maciejska, A.; Pomierny, B.; Krzyżanowska, 
W.; Starek-Świechowicz, B.; Bystrowska, B.; Broniowska, Ż.; Kazek, G.; Budziszewska, B.; Neurotoxic. Res. 2020, 37, 683.

5. Ionta, M.; Ferreira-Silva, G. A.; Niero, E. L.; Costa, É. D. M.; Martens, A. A.; Rosa, W.; Soares, M. G.; Machado-Santelli, G. M.; Lago, J. H. G.; Santos, M. H.; Molecules 2015, 20, 12804. 6. Sales, L.; de Sousa, G. R.; Ferreira-Silva, G.; Castro-Gamero, A. M.; Ionta, M.; de Oliveira, J. C.; Anticancer Drugs 2016, 28,298

7. Suzuki, T.; Kitamura, S.; Khota, R.; Sugihara, K.; Fujimoto, N.; Ohta, S.; Toxicol. Appl. Pharmacol. 2005, 203, 9.

8. Rodríguez-Gómez, R.; Zafra-Gómez, A.; Dorival-García, N.; Ballesteros, O.; Navalón, A.; Talanta 2015, 134, 657.

9. Liu, W.; Wei, D.; Liu, Q.; Du, Y.; Chemosphere 2016, 154, 491.

10. Barbosa, T. C.; Nascimento, L. É. D.; Bani, C.; Almeida, T.; Nery, M.; Santos, R. S.; Menezes, L. R. O.; Zielinska, A.; Fernandes, A. R.; Cardoso, J. C.; Jäger, A.; Jäger, E.; SanchezLopez, E.; Nalone, L.; Souto, E. B.; Severino, P.; Toxics 2019 7,51 .

11. Liyanaarachchi, G. D.; Samarasekera, J. K. R. R.; Mahanama, K. R. R.; Hemalal, K. D. P.; Ind. Crops Prod. 2018, 111, 597.

12. Craythorne, E.; Al-Niami, F.; Medicine 2017, 45, 429.

13. Watson, M.; Holman, D. M.; Maguire-Eisen, M.; Semin. Oncol. Nurs. 2016, 32, 241.

14. Navarro, M.; Arnaez, E.; Moreira, I.; Quesada, S.; Azofeifa, G.; Wilhelm, K.; Vargas, F.; Chen, P.; Foods 2019, 8, 384.

15. Nguyen, L. H.; Venkatraman, G.; Sim, K. Y.; Harrison, L. J.; Phytochemistry 2005, 66, 1718.

16. Yamaguchi, F.; Ariga, T.; Yoshimura, Y.; Nakazawa, H.; J. Agric. Food Chem. 2000, 48, 180.

17. Doriguetto, A. C.; Martins, F. T.; Ellena, J.; Salloum, R.; dos Santos, M. H.; Moreira, M. E. C.; Schneedorf, J. M.; Nagem, T. J.; Chem. Biodiversity 2007, 4, 488.

18. Lushchak, V. I.; Chem.-Biol. Interact. 2014, 224, 164.

19. Poprac, P.; Jomova, K.; Simunkova, M.; Kollar, V.; Rhodes, C. J.; Valko, M.; Trends Pharmacol. Sci. 2017, 38, 592.

20. Pisoschi, A. M.; Pop, A.; Eur. J. Med. Chem. 2015, 97, 55.

21. Sosa, V.; Moliné, T.; Somoza, R.; Paciucci, R.; Kondoh, H.; LLeonart, M. E.; Ageing Res. Rev. 2013, 12, 376.

22. Saidi, L.; Rocha, D. H. A.; Talhi, O.; Bentarzi, Y.; Nedjar-Kolli, B.; Bachari, K.; Paz, F. A. A.; Helguero, L. A.; Silva, A. M. S.; ChemMedChem 2019, 14, 1041.

23. Gholampour, M.; Ranjbar, S.; Edraki, N.; Mohabbati, M.; Firuzi, O.; Khoshneviszadeh, M.; Bioorg. Chem. 2019, 88, 102967.

24. Hou, W.; Zhang, G.; Luo, Z.; Su, L.; Xu, H.; Chem. Biol. Drug Des. 2019, 93, 473.

25. Mareddy, J.; Suresh, N.; Kumar, C. G.; Kapavarapu, R.; Jayasree, A.; Pal, S.; Bioorg. Med. Chem. Lett. 2017, 27, 518.

26. Torres, L. M. F. C.; Almeida, M. T.; Santos, T. L.; Marinho, L. E. S.; de Mesquita, J. P.; da Silva, L. M.; dos Santos, W. T. P.; Martins, H. R.; Kato, K. C.; Alves, E. S. F.; Liao, L. M.; de Magalhães, M. T. Q.; de Mendonça, F. G.; Pereira, F. V.;
Resende, J. M.; Bemquerer, M. P.; Rodrigues, M. A.; Verly, R. M.; Colloids Surf., B 2019, 177, 94.

27. Di Pietro, O.; Alencar, N.; Esteban, G.; Viayna, E.; Szałaj, N.; Vázquez, J.; Juárez-Jiménez, J.; Sola, I.; Pérez, B.; Solé, M.; Unzeta, M.; Muñoz-Torrero, D.; Luque, F. J.; Bioorg. Med. Chem. 2016, 24, 4835.

28. Banerji, B.; Chandrasekhar, K.; Sreenath, K.; Roy, S.; Nag, S.; Saha, K. D.; ACS Omega 2018, 3, 16134.

29. Yamada, M.; Takahashi, T.; Hasegawa, M.; Matsumura, M.; Ono, K.; Fujimoto, R.; Kitamura, Y.; Murata, Y.; Kakusawa, N.; Tanaka, M.; Obata, T.; Fujiwara, Y.; Yasuike, S.; Bioorg. Med. Chem. Lett. 2018, 28, 152.

30. Saraiva, M. T.; Krüger, R.; Baldinotti, R. S. M.; Lenardão, E. J.; Luchese, C.; Savegnago, L.; Wilhelm, E. A.; Alves, D.; J. Braz. Chem. Soc. 2016, 27, 41.

31. Tan, W.; Li, Q.; Li, W.; Dong, F.; Guo, Z.; Int. J. Biol. Macromol. 2016, 82, 404.

32. Dias, M. C. F.; Gularte, T. Q.; Teixeira, R. R.; Santos, J. A. N.; Pilau, E. J.; Mendes, T. A. O.; Demuner, A. J.; dos Santos, M. H.; J. Braz. Chem. Soc. 2019, 30, 97.

33. MedChem Designer, version 3.1.0.30; Simulations Plus, Inc, Lancaster, USA, 2011.

34. Agência Nacional de Vigilância Sanitária (ANVISA); Resolução - RDC No. 30, de 1 de junho de 2012, Aprova o Regulamento Técnico Mercosul sobre Protetores Solares em Cosméticos e Dá Outras Providências; Ministério da Saúde: Brasília, Brazil, 2012, available at http://bvsms.saude. gov.br/bvs/saudelegis/anvisa/2012/rdc0030_01_06_2012. html\#: : text=Aprova\% 20o\%20Regulamento $\% 20$ T\%C3\%A9cnico\%20Mercosul,Regulamento\%20aprovado $\% 20$ pelo\%20Decreto\%20n, accessed in October 2020.

35. Agência Nacional de Vigilância Sanitária (ANVISA); Resolução - RDC No. 48, de 16 de março de 2006, Aprova o Regulamento Técnico sobre Lista de Substâncias que Não Podem Ser Utilizadas em Produtos de Higiene Pessoal, Cosméticos e Perfumes; Ministério da Saúde: Brasília, Brazil, 2006, available at http://bvsms.saude.gov.br/bvs/saudelegis/ anvisa/2006/rdc0048_17_03_2006.html\#: :text=Fica\%20 proibido $\% 20 \mathrm{o} \% 20 \mathrm{uso} \% 20 \mathrm{em}$,ou $\% 20 \mathrm{t} \% \mathrm{C} 3 \% \mathrm{~B} 3 \mathrm{xicas} \% 20$ para\%20a\%20reprodu\%C3\%A7\%C3\%A3o, accessed in October 2020.

36. Heo, S.; Hwang, H. S.; Jeong, Y.; Na, K.; Carbohydr. Polym. 2018, 195, 534.

37. Krause, M.; Frederiksen, H.; Sundberg, K.; Jørgensen, F. S.; Jensen, L. N.; Nørgaard, P.; Jørgensen, C.; Ertberg, P.; Juul, A.; Drzewiecki, K. T.; Skakkebaek, N. E.; Andersson, A. M.; Environ. Int. 2018, 110, 51.

38. do Nascimento, L. F.; dos Santos, E. P.; de Aguiar, A. P.; Rev. Virtual Quim. 2014, 6, 190.

39. Sousa, M. S. B.; Vieira, L. M.; de Lima, A.; Braz. J. Food Technol. 2011, 14, 202. 
40. Rice-Evans, C. A.; Miller, N. J.; Paganga, G.; Free Radicals Biol. Med. 1996, 20, 933.

41. Liu, H.-T.; Ho, Y.-S.; Food Sci. Hum. Wellness 2018, 7, 134.

42. Wright, J. S.; Johnson, E. R.; DiLabio, G. A.; J. Am. Chem. Soc. 2001, 123, 1173.

43. Brand-Williams, W.; Cuvelier, M. E.; Berset, C.; LWT - Food Sci. Technol. 1995, 28, 25.

44. Bray, F.; Ferlay, J.; Soerjomataram, I.; Siegel, R. L.; Torre, L. A.; Jemal, A.; Ca-Cancer J. Clin. 2018, 68, 394.

45. AlFakeeh, A.; Brezden-Masley, C.; Curr. Oncol. 2018, 25, S18.

46. Weiss, R. B.; Christian, M. C.; Drugs 1993, 46, 360.

47. Napolitano, S.; Brancaccio, G.; Argenziano, G.; Martinelli, E.; Morgillo, F.; Ciardiello, F.; Troiani, T.; Cancer Treat. Rev. 2018, 69, 101.

48. Davies, H.; Bignell, G. R.; Cox, C.; Stephens, P.; Edkins, S.; Clegg, S.; Teague, J.; Woffendin, H.; Garnett, M. J.; Bottomley, W.; Davis, N.; Dicks, E.; Ewing, R.; Floyd, Y.; Gray, K.; Hall, S.; Hawes, R.; Hughes, J.; Kosmidou, V.; Menzies, A.; Mould, C.; Parker, A.; Stevens, C.; Watt, S.; Hooper, S.; Jayatilake, H.; Gusterson, B. A.; Cooper, C.; Shipley, J.; Hargrave, D.; Pritchard-Jones, K.; Maitland, N.; Chenevix-Trench, G.; Riggins, G. J.; Bigner, D. D.; Palmieri, G.; Cossu, A.; Flanagan, A.; Nicholson, A.; Ho, J. W. C.; Leung, S. Y.; Yuen, S. T.; Weber, B. L.; Seigler, H. F.; Darrow, T. L.; Paterson, H.; Wooster, R.; Stratton, M. R.; Futreal, P. A.; Nature 2002, 417, 949.

49. Abbotts, R.; Jewell, R.; Nsengimana, J.; Maloney, D. J.; Simeonov, A.; Seedhouse, C.; Elliott, F.; Laye, J.; Walker, C.; Jadhav, A.; Grabowska, A.; Ball, G.; Patel, P. M.; NewtonBishop, J.; Wilson, D. M.; Madhusudan, S.; Oncotarget 2014, 5,3273 .

50. McCubrey, J. A.; Steelman, L. S.; Chappell, W. H.; Abrams, S. L.; Wong, E. W. T.; Chang, F.; Lehmann, B.; Terrian, D. M.; Milella, M.; Tafuri, A.; Stivala, F.; Libra, M.; Basecke, J.; Evangelisti, C.; Martelli, A. M.; Franklin, R. A.; Biochim. Biophys. Acta, Mol. Cell Res. 2007, 1773, 1263.

51. Cseh, B.; Doma, E.; Baccarini, M.; FEBS Lett. 2014, 588, 2398.

52. Wan, P. T. C.; Garnett, M. J.; Roe, S. M.; Lee, S.; NiculescuDuvaz, D.; Good, V. M.; Project, C. G.; Jones, C. M.; Marshall, C. J.; Springer, C. J.; Barford, D.; Marais, R.; Cell 2004, 116, 855.
53. Maurer, G.; Tarkowski, B.; Baccarini, M.; Oncogene 2011, 30, 3477.

54. Lapenna, S.; Giordano, A.; Nat. Rev. Drug Discovery 2009, 8, 547.

55. Daveri, E.; Valacchi, G.; Romagnoli, R.; Maellaro, E.; Maioli, E.; Evidence-Based Complementary Altern. Med. 2015, 2015, 545838.

56. Farooq, S.; Hussain, A.; Qurishi, M. A.; Hamid, A.; Koul, S.; Anti-Cancer Agents Med. Chem. 2018, 18, 1531.

57. Begnini, K. R.; Duarte, W. R.; da Silva, L. P.; Buss, J. H.; Goldani, B. S.; Fronza, M.; Segatto, N. V.; Alves, D.; Savegnago, L.; Seixas, F. K.; Collares, T.; Biomed. Pharmacother. 2017, 91,510 .

58. Osorio, L. S.; Ionta, M.; Demuner, A. J.; de Sousa, B. L.; Ferraz, G. O.; Varejão, E. V. V.; Ferreira-Silva, G. A.; Pilau, E. J.; Silva, E.; dos Santos, M. H.; J. Braz. Chem. Soc. 2020, 31, 2500.

59. Trachootham, D.; Alexandre, J.; Huang, P.; Nat. Rev. Drug Discovery 2009, 8, 579.

60. Kruk, J.; Duchnik, E.; Asian Pac. J. Cancer Prev. 2014, 15, 561.

61. Zhang, W.; Shu, X. O.; Li, H.; Yang, G.; Cai, H.; Ji, B. T.; Gao, J.; Gao, Y. T.; Zheng, W.; Xiang, Y. B.; J. Natl. Cancer Inst. 2012, 104, 1173.

62. Chikara, S.; Nagaprashantha, L. D.; Singhal, J.; Horne, D.; Awasthi, S.; Singhal, S. S.; Cancer Lett. 2018, 413, 122.

63. Bansal, A.; Simon, M. C.; J. Cell Biol. 2018, 217, 2291.

64. Mansur, M. C. P. P. R.; Leitão, S. G.; Cerqueira-Coutinho, C.; Vermelho, A. B.; Silva, R. S.; Presgrave, O. A. F.; Leitão, Á. A. C.; Leitão, G. G.; Ricci-Júnior, E.; Santos, E. P.; Rev. Bras. Farmacogn. 2016, 26, 251.

65. GraphPad Prism ${ }^{\circledR}$, version 5.0; GraphPad Software, San Diego, CA, USA, 2007.

66. Azevedo-Barbosa, H.; Ferreira-Silva, G. Á.; Silva, C. F.; de Souza, T. B.; Dias, D. F.; de Paula, A. C. C.; Ionta, M.; Carvalho, D. T.; Toxicol. In Vitro 2019, 59, 150.

67. GuavaSoft, version 2.7; EMD Millipore Corporation, Hayward, CA, USA, 2013.
Submitted: July 23, 2020

Published online: October 27, 2020 